\title{
Ambipolar discotic liquid crystals built around platinum diimine- dithiolene cores
}

Franck Camerel, ${ }^{1, *}$ Grégory Albert, ${ }^{1}$ Frédéric Barrière, ${ }^{1}$ Corinne Lagrost, ${ }^{1}$ Marc Fourmigué, ${ }^{1}$ Olivier Jeannin ${ }^{1}$

1) Univ Rennes, CNRS, ISCR - UMR 6226, F-35000 Rennes, France. Email : franck.camerel@univ-rennes1.fr

\begin{abstract}
Platinum diimine dithiolene complexes bearing mesogenic groups on one or both ligands have been prepared through an original ligand metathesis reaction to introduce the dithiolene ligand. The neutral diimine ligands, the intermediate platinum dichloride diimine complexes and the target compounds were characterized by a combination of electronic (electrochemistry, absorption and emission spectroscopy, DFT calculations) and structural (SAXS, DSC) tools. Several novel liquid crystalline platinum diimine-dithiolene were identified over a large temperature range, furthermore endowed with ambipolar properties, associated with the high reversibility of both oxidation and reduction processes.
\end{abstract}

\section{Introduction}

Discotic Liquid Crystals (DLSs) have attracted a lot of interest due to their charge transport properties, their ability to be easily aligned in thin films and their self-healing capability for applications in optoelectronic as active layers in OLED, OFET and solar cells. ${ }^{[1]}$ Ambipolar DLCs are particularly appealing since they are able to simultaneously carry electrons and holes and new designs are developed to obtain novel ambipolar semiconducting soft materials. ${ }^{[2]}$ 
Most examples of DLC semiconductors with ambipolar properties are purely organic compounds, such as triphenylenes or phthalocyanines, ${ }^{[3]}$ while ambipolar charge transport has also been reported in triazine-based columnar liquid crystals. ${ }^{[4]}$ In the latter, the triazine discotic core acts as an electron accepting unit whereas the peripheral thiophene units provide electrondonating properties. Another organic ambipolar DLC was obtained by covalently grafting a phtalocyanine as an electron-donor and a fullerene as an electron acceptor. ${ }^{[5]}$ Muller and coworkers also reported an ambipolar DLC with n-type perylene monoimide (PMI) covalently linked around p-type hexabenzocoronene core. ${ }^{[6]}$ Large ambipolar carrier mobility was also found in discotic liquid crystalline truxenes substituted with alkyl chains at bay-positions. ${ }^{[7]}$ More recently, a DLC material, consisting of a planarized triphenylborane mesogen, was reported to form a hexagonal columnar LC phase exhibiting ambipolar carrier transport properties with electron and hole mobility. ${ }^{[8]}$

Besides, the number of ambipolar DLC built around metal complexes remains scarce. The only examples involve gadolinium or zinc phthalocyanines ${ }^{[9,10]}$ and very recently, ambipolar carrier mobility was mentioned for a series of liquid crystalline platinum (II) complexes with 2phenylpyridine derivatives as the main ligand and 5-substituted tetrazole as the auxiliary ligand. ${ }^{[11]}$

In that respect, neutral platinum diimine-dithiolene complexes formulated as $\left[\mathrm{Pt}^{\mathrm{II}}(\text { diimine)(dithiolato) }]^{0}\right.$ are an interesting class of ambipolar complexes with heteroleptic ligands. Indeed, the diimine fragment is prone to undergo reduction at relatively accessible potentials whereas the electron-rich dithiolene fragment is easily oxidized. Several research groups $^{[12]}$ and in particular the group of R. Eisenberg ${ }^{[13]}$ have developed the synthesis of platinum diimine-dithiolene complexes to understand and to modulate their photophysical and redox properties. Complexes have been prepared by using 2,2'-bipyridine or 1,10phenanthroline as diimine ligands and 1,2-benzenedithiolates, 1,1-dithiolates or 1,2- 
ethylenedithiolates as dithiolate ligands. These square planar $\left[\mathrm{Pt}^{\mathrm{II}}(\text { diimine })(\text { dithiolato })\right]^{0}$ complexes also display solution luminescence and solvatochromic absorption bands which are attributed to common charge-transfer bands. Diimine-dithiolene complexes have also been proposed as light harvester in the visible region for light driven aqueous reduction to hydrogen ${ }^{[14]}$ but also in solar cells. ${ }^{[15]}$ Crown ethers have been introduced on the dithiolate ligand in the [Pt(NN)(SS)] system for developing optical and electrochemical sensors for alkali metal cations. ${ }^{[16]}$

Surprisingly and to the best of our knowledge, only one liquid crystalline material build around a metal diimine-dithiolene core has been described up to now by Ho-Chol Chang and coworkers in 2011. ${ }^{[17]}$ A platinum complex having an asymmetric molecular structure derived from 1,2-benzenedithiolato (bdt) and a bipyridine ligand carrying ramified C8 or C10 carbon chains forms a columnar mesophase of hexagonal symmetry over a large temperature range from $-18{ }^{\circ} \mathrm{C}$ up to $194{ }^{\circ} \mathrm{C}$. This complex undergoes quasi reversible one-electron reduction at $-1.89 \mathrm{~V}$ vs $\mathrm{Fc} / \mathrm{Fc}^{+}$that corresponds to bpy-based reduction processes. The dithiolate ligand can also be oxidized but according to a slow electrochemical process because the peak-to-peak separation of this oxidation process is found to be $0.17 \mathrm{~V}$, far above the expected value for a nernstian one-electron transfer process $(0.059 \mathrm{~V})$.

Thus, to obtain new ambipolar discotic liquid crystals, four diimine-dithiolene complexes, differently functionalized by long carbon chains or cyanobiphenyl fragments, have been developed herein by using a ligand metathesis between dichloroplatinum diimine derivatives and tin or nickel dithiolene complexes as dithiolate ligand precursors (Scheme 1). The platinum complexes carry a 5,6-dihydro-1,4-dithiin-2,3-dithiolato (dddt) ligand (in 1a-c) or a 1,2-bis(3,4-bis(dodecyloxy)phenyl)ethene-1,2-bis(thiolato) $\left(\mathrm{C}_{12} \mathrm{dt}\right)$ ligand (in $2 \mathbf{a}, \mathbf{2 b}$ and 2d) and as diimine ligand, a functional bipyridine carrying, either tris-dodecyloxyphenyl fragments connected through an amide linker and noted bpyC ${ }_{12}$ (in 1a and 2a) or cyanobiphenyl 
fragments connected through an ester linker carrying a C10 carbon chains and noted bpyCBP (in $\mathbf{1 b}$ and $\mathbf{2 b}$ ). Compounds $\mathbf{1 c}$ and $\mathbf{2 d}$ have been synthesized as reference compounds. The electronic properties of these complexes and their precursors have been characterized by absorption and luminescence spectroscopies as well as by cyclic voltammetry and DFT calculations. The structural properties of these compounds were also investigated by a combination of optical microscopy under crossed polarizers, DSC analyses and small angle Xray diffraction. The results obtained confirmed that these compounds have indeed a strong ambipolar character with good reversibility and that some of them also display liquid crystalline properties over a large temperature range.
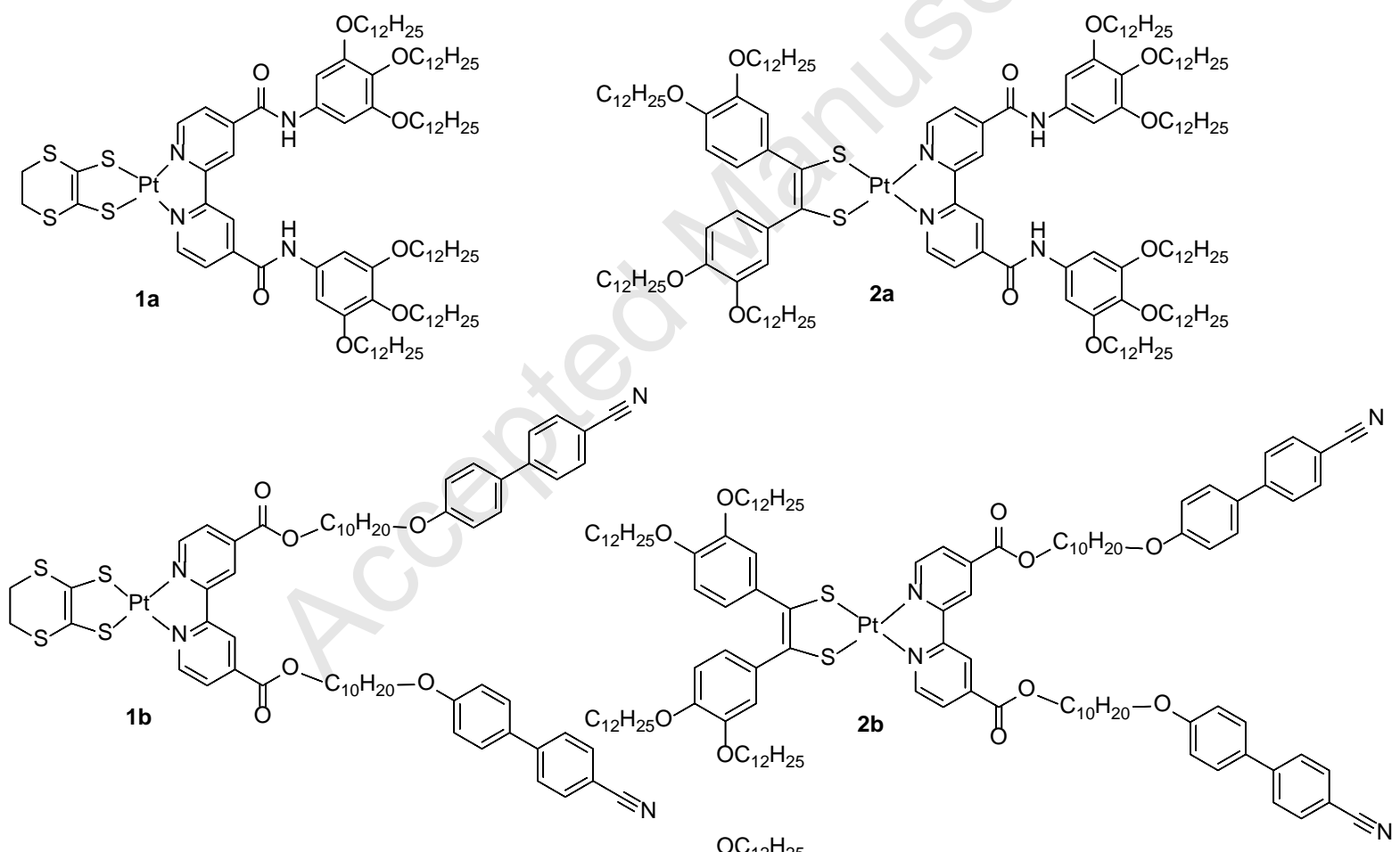<smiles></smiles>

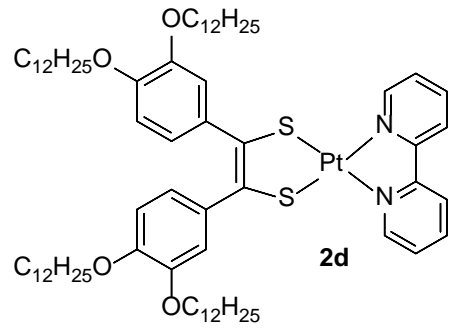

Scheme 1. Chemical structure and name of the functional diimine-dithiolene complexes investigated. 


\section{Results and discussion}

\section{Synthesis and characterization}

Synthetic routes toward the functional diimine-dithiolene compounds are presented in Scheme

2. Full synthetic details are given in the experimental part.

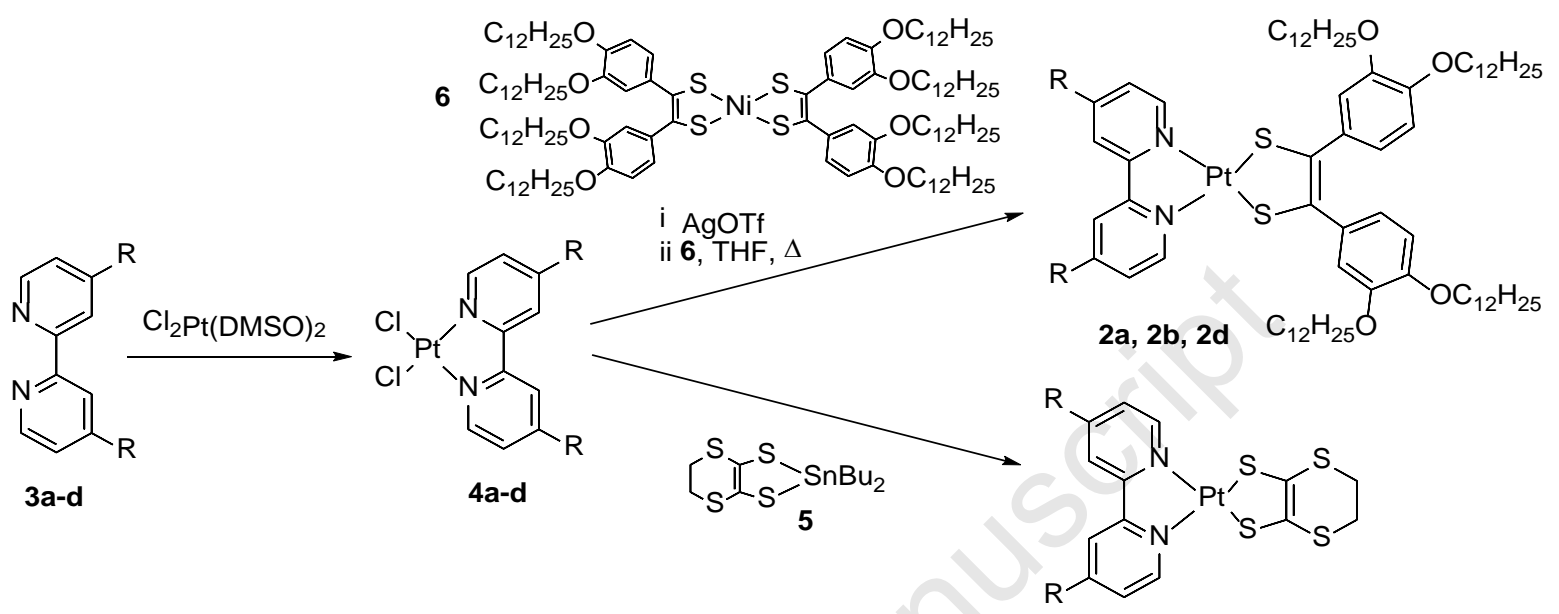

1a, 1b, 1c

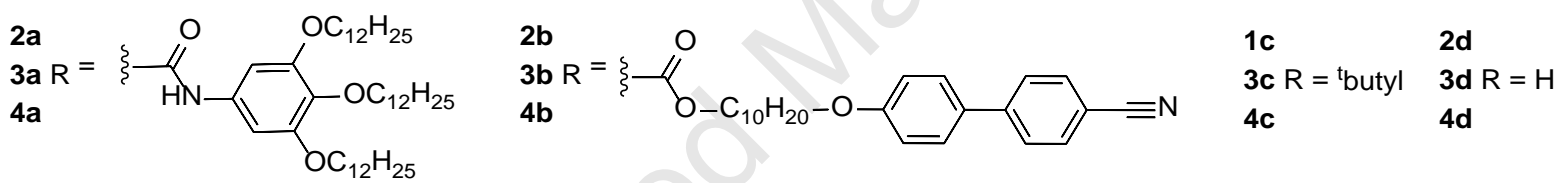

Scheme 2. Synthetic routes used for the preparation of the functional diimine-dithiolene platinum complexes.

First, functional bipyridine carrying either tris-dodecyloxyphenyl fragments connected through an amide linker (bpyC12 3a), or cyanobiphenyl fragments connected through ester linker carrying a C10 carbon chains (bpyCBP 3b) were reacted with 1 eq. of $\mathrm{PtCl}_{2}(\mathrm{DMSO})_{2}$ to afford the corresponding dichloroplatinum diimine complexes $\mathbf{4 a}$ and $\mathbf{4 b}$ in 76 and $52 \%$ yield, respectively. The synthesis of these two functional bipyridine molecules $\mathbf{3 a}$ and $\mathbf{3 b}$ is fully described in the experimental part. For introducing the dddt dithiolene ligand, dichloroplatinum diimine complexes 4a-b were then reacted with one equivalent of 2,2-dibutyl-5,6-dihydro1,3,2-dithiastannolo[4,5-b][1,4]dithiin 5 in acetone to afford $\mathbf{1 a}$ (75\% yield) and $\mathbf{1 b}$ (63\% 
yield) as green powders. For introducing the $\mathrm{C}_{12} \mathrm{dt}$ dithiolene ligand to prepare in the $\mathbf{2} \mathbf{a}$ and $\mathbf{2} \mathbf{b}$ complexes, the dichloroplatinum diimine complexes $\mathbf{4 a - b}$ were first reacted with silver triflate in order to exchange the chloride ligand by the more labile triflate anion. The triflate derivative was then refluxed with the neutral nickel bis(dithiolene) complex 6 in THF to afford after purification the expected compounds $\mathbf{2 a}$ and $\mathbf{2 b}$. EDX analyses have also revealed that there is no trace of nickel in the isolated compounds.

The reference compounds $\mathbf{1 c}$ and $\mathbf{2 d}$ were prepared in a similar way. The dddt derivative $\mathbf{1 c}$ was readily obtained from the reaction of the dichloroplatinum diimine complex $\mathbf{4 c}$ with one equivalent of $\mathbf{5}$ in acetone, while $\mathbf{2 d}$ was also obtained in $28 \%$ yield by first reacting $\left[\mathrm{PtCl}_{2}\right.$ (bpy)] 3d with silver triflate followed by reaction with $\mathbf{6}$.

The purity and the molecular structure of all the compounds were confirmed by elemental analyses, ${ }^{1} \mathrm{H}$ NMR and ${ }^{13} \mathrm{C}$ NMR spectroscopy, UV-vis, mass spectroscopy and IR spectroscopy. The introduction of $\mathrm{Cl}_{2} \mathrm{Pt}$ on the bipyridine fragments is characterized by a downfield shift of the ${ }^{1} \mathrm{H}$ signal of bipyridine protons. The introduction of the dddt fragment in place of the two chloride ligands results in a singlet between 2.61 and $3.51 \mathrm{ppm}$ integrating for $4 \mathrm{H}$ corresponding to the hydrogen atoms of the $\mathrm{S}-\mathrm{CH}_{2}$ groups. Despite several attempts in $\mathrm{CDCl}_{3}$, $\mathrm{d}_{6}$-DMSO and $\mathrm{CD}_{2} \mathrm{Cl}_{2}$ at room temperature but also at $60{ }^{\circ} \mathrm{C}$, the two complexes $\mathbf{2 a}$ and $\mathbf{2 b}$ bearing long alkyl chains on both the dithiolene and the diimine ligands could not be properly characterized by NMR spectroscopy, likely due to strong aggregation effects in solution (vide infra). However, the optical, thermal and electronic properties as well as the mass spectroscopy and the elemental analysis unambiguously confirmed the formation of the expected complexes.

\section{X-ray structure of 1c}

Single-crystals suitable for X-ray diffraction of the model compound 1c with the dddt and $(\mathrm{tBu})_{2}$ bpy ligands were obtained in $\mathrm{CHCl}_{3}$ by slow diffusion of pentane. Crystallographic data 
are given in Table S1-S4. This compound crystallizes as chloroform solvate in the triclinic system, space group $P \overline{1}\left(\mathrm{a}=7.2116(4) \AA \AA ; \mathrm{b}=13.8530(9) \AA ; \mathrm{c}=15.3854(10) \AA ; \alpha \alpha=69.100(2)^{\circ}\right.$; $\left.\beta=86.336(2)^{\circ} ; \gamma=82.782(2)^{\circ} ; V=1424.23(15) \AA^{3}, Z=2\right)$. Figure 1 shows the atomic numbering scheme and a projection of the crystalline structure along $a$. The asymmetric unit contains one complex and one chloroform molecule, both in general position. The X-ray crystal structure confirms the chemical structure of the complex. The platinum atom is in a pseudo square planar environment (Pt-N1 = 2.053(4) $\AA$; Pt-N2 = 2.056(3) Å; Pt-S4 = 2.2544(11) $\AA$; $\mathrm{Pt}-\mathrm{S} 1=2.2574(12) \AA \AA \mathrm{N} 1-\mathrm{Pt}-\mathrm{N} 2=78.87(14)^{\circ} ; \mathrm{N} 1-\mathrm{Pt}-\mathrm{S} 4=96.26(10)^{\circ} ; \mathrm{N} 2-\mathrm{Pt}-\mathrm{S} 1=$ 96.51 $(10)^{\circ}$; S4-Pt-S1 $\left.=89.13(4)^{\circ}\right)$. The dithiolene fragment and the bipyridine fragment are not coplanar, bur slightly twisted by $16.89^{\circ}$ around the platinum center. It can also be noticed that the ethylenic bridge of the dddt ligand is bended out of plane of the complex by $83^{\circ}$. The molecules are packed in a head-to-tail fashion along the $a$ axe (Figure 1b), the best way to accommodate the bulky ${ }^{t} \mathrm{Bu}$ groups. Along the stack, bipyridine fragments exhibit a bond-overring overlap, preventing the formation of short platinum-platinum contacts. The shortest platinum-platinum distance along the stack is indeed $5.348 \AA$. 

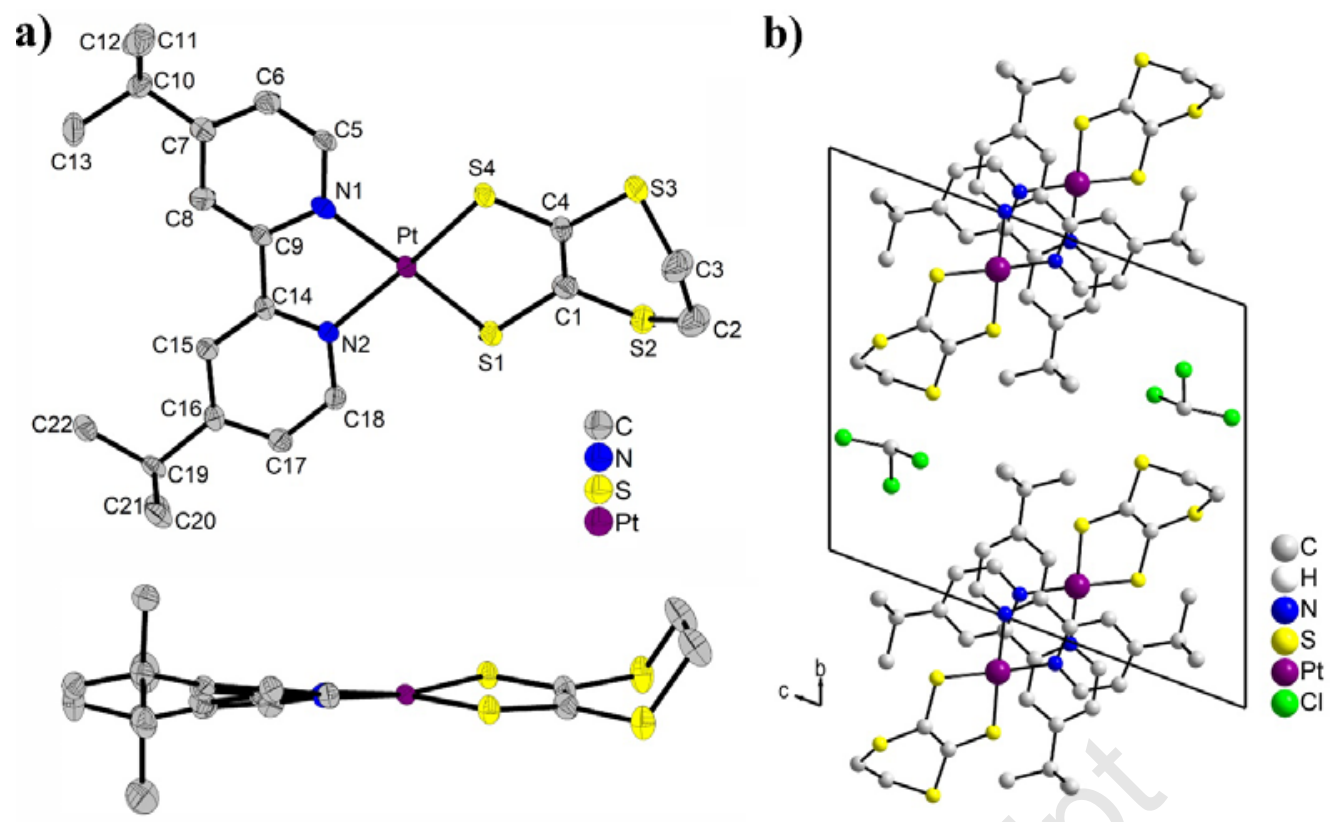

Figure 1. a) ORTEP diagram of 1c from the top and from the side with $50 \%$ thermal contours for all atoms and the atomic numbering scheme. $\mathrm{H}$ atoms have been omitted for the sake of clarity; b) Projection of the crystalline structure along the $a$ axis.

\section{Spectroscopic properties in solution}

Spectroscopic data for all the complexes and their precursors in diluted $\mathrm{CH}_{2} \mathrm{Cl}_{2}$ solutions are gathered in Table 1. The absorption spectra are presented in Figure 2a and in Figures S1-S5. The absorption spectrum of the bpyC 12 ligand 3a shows a main broad absorption band exhibiting a maximum at $298 \mathrm{~nm}\left(\varepsilon \sim 22450 \mathrm{M}^{-1} \mathrm{~cm}^{-1}\right)$ with a shoulder at $338 \mathrm{~nm}$ (Figure S1). These absorption bands are assigned to $\pi-\pi^{*}$ and $n-\pi^{*}$ transitions localized on the bipyridine core and on the alkoxyphenyl fragments, respectively. ${ }^{[18]}$ The absorption spectrum of the bpyCBP ligand $\mathbf{3 b}$ also displays an absorption band centred at $298 \mathrm{~nm}$ but the band is much sharper and the associated extinction coefficient is much higher compared with 3a (Figure 2a and S1). This absorption band is assigned to $\pi-\pi *$ transitions localized on the bipyridine core but also to $\pi-\pi^{*}$ transitions localized on the cyanobiphenyl fragments. ${ }^{[19]}$ Coordination of the $\mathrm{PtCl}_{2}$ fragment leads to a new absorption band at $412 \mathrm{~nm}$ for $\mathbf{4 a}$ and $429 \mathrm{~nm}$ for $\mathbf{4 b}$ (Figure S2 
and 2a) with weak extinction coefficients. These absorption bands are readily associated to the charge transfer transition corresponding to excitations from a filled $\mathrm{Pt}(\mathrm{d})$ orbital to an unoccupied $\pi^{*}$ diimine orbital (MLCT). ${ }^{[20]}$ Introduction of the $\operatorname{dddt}^{2-}$ in place of the chloride ligands is characterized in 1a by an additional absorption band on the spectrum at even lower energy, associated to mixed metal ligand-to-ligand charge transfer transition (MMLL'CT) corresponding to excitation from the electron donor dithiolate ligand having orbital contributions from the metal ion to the electron acceptor bipyridine ligand (Figure 2a and S3). ${ }^{[21]}$ With the $\mathrm{C}_{12} \mathrm{dt}$ dithiolene ligand, the position of this MMLL'CT band in $\mathbf{1 b}$ is weakly affected by the nature of the bipyridine ligand and is located around 630-660 nm (Figure S4). On the contrary, with the dddt ligand, the MMLL'CT band is located at $635 \mathrm{~nm}$ in 1c (Figure S5) whereas this band is red-shifted to 712 and $770 \mathrm{~nm}$ for $\mathbf{1 a}$ and $\mathbf{1 b}$, respectively. An MLCT band is present for all the complexes and it can be noticed that with the bpyC 12 ligand, the MLCT band of the complexes is slightly blue-shifted compare to the bpyCBP ligand. Solidstate absorption spectra of some complexes have been measured (Figure S6). The absorption maxima are close to those measured in solution and only a broadening of the absorption bands is observed. Solids-state absorption spectra of the platinum diimine-dithiolene complexes clearly display the LLCT at low energy, showing that the charge transfer is also effective in solid-state.

The luminescence properties of all the compounds were also investigated in $\mathrm{CH}_{2} \mathrm{Cl}_{2}$ solutions. The bpyC $\mathrm{C}_{12}$ diimine $\mathbf{3 a}$, its $\mathrm{PtCl}_{2}$ complex 4a and the dddt complex 1a are nonluminescent. On the other hand, spectrum of complex $\mathbf{1 b}$ with the other $\mathrm{C}_{12} \mathrm{dt}$ dithiolene ligand shows an emission band centered at $485 \mathrm{~nm}$ upon excitation in the MLCT band at $430 \mathrm{~nm}$ (Figure 2b). For all complexes carrying a bpyCBP ligand 3b, an emission band is observed around $370 \mathrm{~nm}$ upon excitation at $300 \mathrm{~nm}$. This emission is attributed to the presence of cyanobiphenyl fragments (Figure S6). All the other complexes show a weak luminescence upon 
excitation in the MLCT band. Introduction of ester or amide functionalities on the bpy fragments (as in $\mathbf{3 a}$ or $\mathbf{3 b}$ ) leads to a red-shift of the emission band, in line with the red-shift of the MLCT band. In fact, with the $\mathrm{C}_{12} \mathrm{dt}$ ligand, complex $\mathbf{2 d}$ absorbs at $348 \mathrm{~nm}$ and emits at 441 nm whereas 2a and $2 \mathbf{b}$ absorb at 430 and $443 \mathrm{~nm}$ and emit at 485 and $520 \mathrm{~nm}$, respectively (Figure 2b). The same observation can be done with the dddt ligand between $\mathbf{1 a}, \mathbf{1 b}$ and $\mathbf{1 c}$. Introduction of the ester or the amide groups leads to the red-shift of both the MLCT and the emission bands. Comparison of two bpyCBP complexes $\mathbf{1} \mathbf{b}$ and $\mathbf{2} \mathbf{b}$ with respectively the dddt and $\mathrm{C}_{12} \mathrm{dt}$ dithiolene ligands shows that the nature of the dithiolate ligand affects the emission properties much more strongly. Indeed, in $\mathbf{1 b}$, the emission appears at $612 \mathrm{~nm}$ and is red-shifted by $92 \mathrm{~nm}$ when compared to $\mathbf{2 b}$. This red-shift is likely attributed to the fact that the dddt ligand is more electron rich than the $\mathrm{C}_{12} \mathrm{dt}$ ligand. No emission has been detected at room temperature upon excitation in the low energy MMLL'CT band. Thus, it appears here that the emission observed at room temperature upon excitation around $450-500 \mathrm{~nm}$ is only due to a ${ }^{3}$ MLCT state and not to the MMLL'CT state. ${ }^{[13]}$

Quantum yields of emission of the various compounds upon excitation in the MLCT band were measured in $\mathrm{CH}_{2} \mathrm{Cl}_{2}$ solutions (Table 1). They are always very low, between 0.1 and $1.2 \%$. The highest quantum yields were found with the free bipyridine $\mathbf{3 b}$. All complexes are luminescent in fluid solution at room temperature and their emission properties can be tuned through ligand variation. It can also be noticed that epifluorescence investigations on solids have revealed that the dichloroplatinum diimine complexes $\mathbf{4 a}$ and $\mathbf{4 b}$ show strong red and yellow luminescence at room temperature upon excitation in the range 350-380 nm, respectively, whereas all the diimine-dithiolene complexes (1a-c, $\mathbf{2 a}, \mathbf{2 b}, \mathbf{2 d}$ ) are deprived of naked-eye luminescence properties in the solid state. For complexes $\mathbf{4 a}$ and $\mathbf{4 b}$, a broad emission centered at 670 and $650 \mathrm{~nm}$, respectively, is observed in solid-state upon excitation at $420 \mathrm{~nm}$ (Figure S8). 
Table 1. Optical data measured in $\mathrm{CH}_{2} \mathrm{Cl}_{2}$ solution at $298 \mathrm{~K}$.

\begin{tabular}{|c|c|c|c|c|}
\hline Compound & $\lambda_{\mathrm{abs}}(\mathrm{nm}) \varepsilon\left(\mathrm{M}^{-1} \cdot \mathrm{cm}^{-1}\right)$ & $\lambda_{\mathrm{ex}}(\mathrm{nm})$ & $\lambda_{\mathrm{F} \max }(\mathrm{nm})$ & $\Phi_{\mathrm{F}}{ }^{[\mathrm{a}]}$ \\
\hline bpyC $_{12}$ 3a & $298(22450)$ & 298 & - & - \\
\hline bруСВР $\mathbf{3 b}$ & 298 (55900) & 298 & 366 & Not measured \\
\hline \multirow[t]{2}{*}{$\mathrm{Cl}_{2} \mathrm{Pt}\left(\mathrm{bpyC} \mathrm{C}_{12}\right) \mathbf{4 a}$} & $300(28300)$ & 300 & - & - \\
\hline & 412 (9630) & 412 & - & - \\
\hline \multirow[t]{2}{*}{$\mathrm{Cl}_{2} \mathrm{Pt}(\mathrm{bpyCBP}) \mathbf{4 b}$} & $300(52600)$ & 300 & 369 & Not measured \\
\hline & $429(3510)$ & 429 & 485 & 0.0023 \\
\hline \multirow[t]{3}{*}{ (dddt)Pt(bpyC 12$) \mathbf{1 a}$} & 316 (23425) & 316 & - & - \\
\hline & $414(9060)$ & 414 & - & - \\
\hline & $712(1630)$ & 712 & - & - \\
\hline \multirow[t]{3}{*}{ (dddt)Pt(bpyCBP) $\mathbf{1 b}$} & $300(61230)$ & 300 & 379 & Not measured \\
\hline & $440(3050)$ & 440 & 612 & 0.0097 \\
\hline & $776(1611)$ & 770 & - & - \\
\hline \multirow[t]{3}{*}{$\left(\mathrm{C}_{12} \mathrm{dt}\right) \operatorname{Pt}\left(\mathrm{bpyC}_{12}\right) \mathbf{2 a}$} & $306(72740)$ & 306 & - & - \\
\hline & 430 (16832) & 430 & 485 & 0.0065 \\
\hline & $626(6900)$ & 626 & - & - \\
\hline \multirow[t]{3}{*}{$\left(\mathrm{C}_{12} \mathrm{dt}\right) \mathrm{Pt}(\mathrm{bpyCBP}) \mathbf{2} \mathbf{b}$} & $298(216050)$ & 298 & 373 & Not measured \\
\hline & 443 (9187) & 443 & 520 & 0.0123 \\
\hline & $816(12876)$ & 640 & - & - \\
\hline \multirow[t]{3}{*}{ (dddt)Pt(tBu ${ }_{2}$ bpy) $\mathbf{1 c}$} & $300(65220)$ & 300 & - & - \\
\hline & $380(7510)$ & 380 & 467 & 0.0033 \\
\hline & $635(9320)$ & 635 & - & - \\
\hline \multirow[t]{3}{*}{$\left(\mathrm{C}_{12} \mathrm{dt}\right) \mathrm{Pt}(\mathrm{bpy}) \mathbf{2 d}$} & 304 (91915) & 304 & - & - \\
\hline & $348(34520)$ & 348 & 441 & 0.0008 \\
\hline & $660(11020)$ & 660 & - & - \\
\hline
\end{tabular}

[a] Determined in $\mathrm{CH}_{2} \mathrm{Cl}_{2}$ solution $\left(\mathrm{c} \sim 10^{-7} \mathrm{M}\right)$ using $\left[\mathrm{Ru}(\mathrm{bpy})_{3}\right] \mathrm{Cl}_{2}$ as reference $\left(\Phi_{\mathrm{F}}=0.059\right.$ in $\left.\mathrm{CH}_{3} \mathrm{CN}, \lambda_{\text {exc }}=450 \mathrm{~nm}\right) .{ }^{[22]}$ All $\Phi_{\mathrm{F}}$ are corrected for changes in refractive index. 

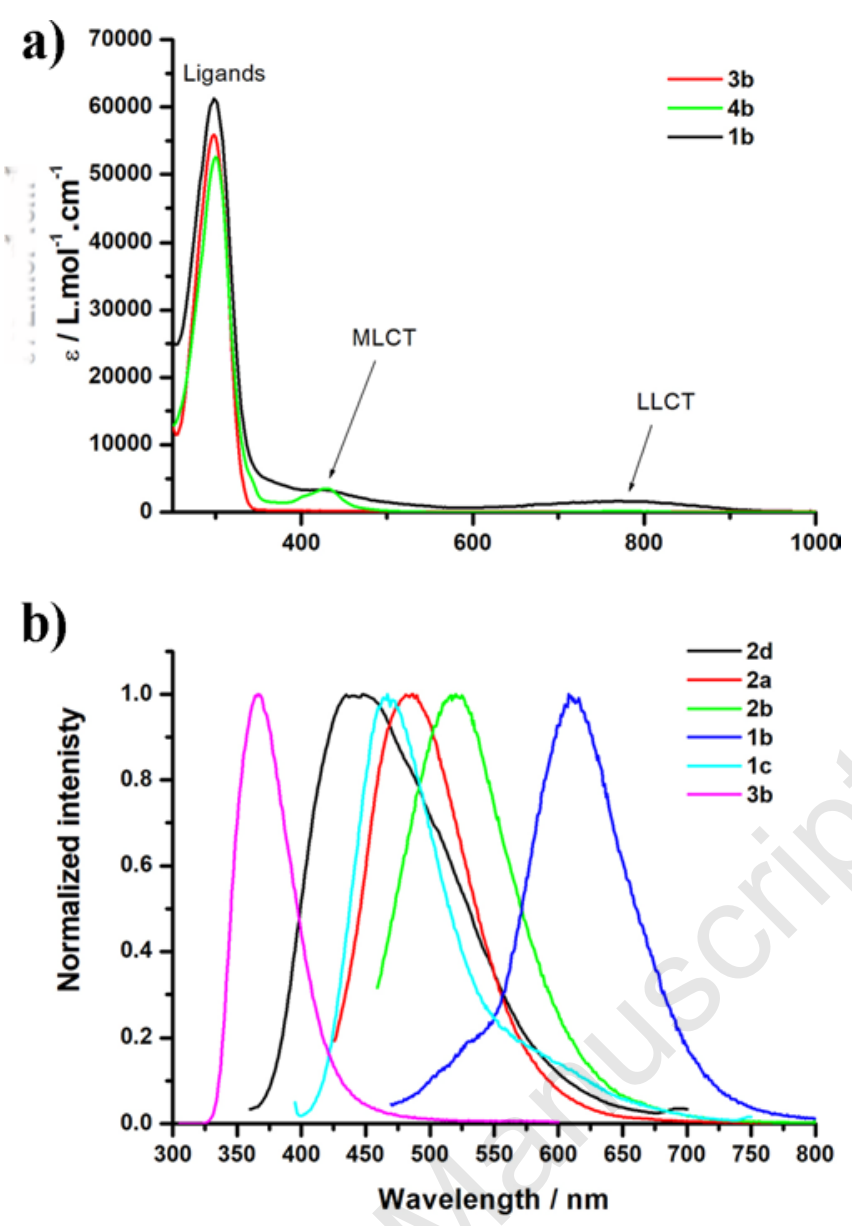

Figure 2. a) UV-Vis absorption spectra in $\mathrm{CH}_{2} \mathrm{Cl}_{2}\left(\mathrm{C} \sim 10^{-5} \mathrm{M}\right)$ of $\mathbf{3 b}, \mathbf{4 b}$ and $\mathbf{1 b}$; b) Normalized emission spectra in $\mathrm{CH}_{2} \mathrm{Cl}_{2}\left(\mathrm{C} \sim 10^{-5} \mathrm{M}\right)$ of all the compounds upon excitation in the MLCT band (except for $\mathbf{3 b}, \lambda_{\mathrm{ex}}=300 \mathrm{~nm}$ ).

\section{Electrochemical investigations}

The electrochemical behavior of complexes and their parent ligands was investigated by cyclic voltammetry in $\mathrm{CH}_{2} \mathrm{Cl}_{2}$ containing $0.2 \mathrm{M} \mathrm{nBu}_{4} \mathrm{NPF}_{6}$ as supporting salts at $293 \mathrm{~K}$. Table 2 gathers the formal potentials $E_{1 / 2}$ derived as the mid-sum of oxidation (Epa) and reduction (Epc) peak potentials (relative to the SCE reference electrode). Electrochemical measurements were run in the $[-2 \mathrm{~V} /+2 \mathrm{~V}]$ potential range.

Cyclic voltammogram of the bipyridine $3 \mathbf{b}$ shows one irreversible reduction process at -1.80 $\mathrm{V}$ (Figure S9), probably due to the reduction of cyanobiphenyl groups ${ }^{[23,24]}$ No reduction 
process has been detected for the bipyridine 3a but an almost irreversible oxidation at $+1.15 \mathrm{~V}$, followed by an ill-defined irreversible oxidation at $+1.5 \mathrm{~V}$ are observed (Figure S10).

After metal complexation, the two bipyridine ligands undergo two successive reversible reductions at $-0.95 \mathrm{~V}$ and $-1.47 \mathrm{~V}$ for $\mathbf{4 a}$ (Figure $\mathrm{S} 11$ ) and at -0.85 and $-1.46 \mathrm{~V}$ for $\mathbf{4 b}$ (Figure S12). Coulometric studies through comparison with ferrocene at $293 \mathrm{~K}$ confirm a one-electron reduction in each case. The two reversible reduction processes correspond to the formation of the monoanion and the dianion, respectively. The electron-withdrawing effect of the ester and amide groups stabilizes the di-reduced product sufficiently to allow bulk electrogeneration of the dianion at room temperature. ${ }^{[25]}$ The ester functionality has a slightly stronger electronwithdrawing effect when compared with the amide function and the $\mathbf{4 b}$ complex is more easily reduced, at least in the first reduction process. The irreversible oxidation observed for $\mathbf{4 a}$ (Figure S11) at $+1.2 \mathrm{~V}$ could be attributed to the oxidation of the amide ligand.

The reference compound with the dddt ligand, 1c, exhibits one reversible reduction at $1.45 \mathrm{~V}$, assigned to a bpy ligand-based reversible reduction (Figure S13). This compound also exhibits two reversible oxidation processes at +0.24 and $+1.02 \mathrm{~V}$, corresponding to the formation of a monocation and a dication, respectively. Both cationic species are stable at the cyclic voltammetry timescale. These oxidation processes are assigned to dddt ligand-based reversible oxidations. It can be noticed that with the known Pt(dddt)(bpy) complex (1d), only one irreversible oxidation system has been observed at $+0.34 \mathrm{~V} .^{[26]}$ The presence of both reversible reduction and oxidation potentials clearly highlights the ambipolar character of our model compound 1c. The cyclic voltamogramm of the $\mathrm{C}_{12} \mathrm{dt}$ complex with bipyridine, $\mathbf{2 d}$ also displays one reversible bpy ligand-based reduction system at $-1.40 \mathrm{~V}$, and two oxidation waves at +0.23 and $+1.01 \mathrm{~V}$, attributed to the $\mathrm{C}_{12} \mathrm{dt}$ ligand (Figure S14). The first oxidation system is reversible while the second one is only partially reversible, probably because of a possible degradation of the $\mathrm{C}_{12} \mathrm{dt}$ fragment. The oxidation potentials of the dddt and $\mathrm{C}_{12} \mathrm{dt}$ fragments are 
very close but the dddt ligand is more stable toward oxidation. In conclusion, both model complexes 1c and 2d exhibit an ambipolar behavior.

Turning now to the four complexes $\mathbf{1 a , b}$ and $\mathbf{2 a , b}, \mathbf{b}$ cyclic voltammogram of $\mathbf{1 b}$ shows two one-electron reversible oxidation processes located at +0.26 and $+0.98 \mathrm{~V}$ (Figure 3). These values are very close to those observed with the dddt-containing complex $\mathbf{1 c}$ and these oxidation processes can be then confidently attributed to the oxidation of the common dddt ligand. $\mathbf{1 b}$ also exhibits two reversible reduction systems at $-1.01 \mathrm{~V}$ and $-1.62 \mathrm{~V}$, respectively (Figure 3). These values are more negatively-shifted than those found for the $\mathrm{PtCl}_{2}$ precursor $\mathbf{4 b}$. This can be explained by the charge transfer that occurs between the dddt and the bpyCBP ligands, as revealed by UV-visible measurements. Through charge transfer, the bpyCBP is more electron rich and thus this fragment becomes more difficult to reduce.

With both the bpyC 12 and dddt ligands, complex 1a exhibits two reversible reduction processes located at -1.08 and $-1.60 \mathrm{~V}$ (Figure S15), showing that the reduction processes are also negatively-shifted compared to $\mathrm{Cl}_{2} \mathrm{Pt}$ precursor 4a. However, only one irreversible oxidation at $1.10 \mathrm{~V}$ is observed, instead of having the expected two oxidations systems of dddt. We postulate that the bpyC $\mathrm{C}_{12}$ ligand oxidation might overlap with the dddt oxidation systems since we observe that the current intensity of the irreversible oxidation at $+1.1 \mathrm{~V}$ is much higher than the current intensity associated with the first or the second reduction process.

The electrochemical activity of the $\mathrm{C}_{12} \mathrm{dt}$ dithiolene complexes $\mathbf{2 a}$ and $\mathbf{2} \mathbf{b}$ with long alkyl chains on both ligands could not be measured due to solubility issues, despite attempts in different solvents, including DMF, $\mathrm{CH}_{2} \mathrm{Cl}_{2}$ and THF. However, in regard to the electrochemical activities of the reference compounds $\mathbf{2 d} \mathbf{d} \mathbf{4 a}$ and $\mathbf{4} \mathbf{b}$, these two compounds should likely display similar electrochemical behaviours with two reversible reduction systems around -0.9 and $-1.5 \mathrm{~V}$ as well as two quasi-reversible oxidation processes around +0.2 and $+0.9 \mathrm{~V}$. To summarize, these electrochemical investigations demonstrate that the diamine-dithiolene core is indeed a very 
attractive platform for preparing ambipolar compounds that can be easily and reversibly oxidized and reduced.

Table 2. Electrochemical data ${ }^{[\mathrm{a}]}$ for all compounds (versus ECS).

\begin{tabular}{|c|c|c|}
\hline Compound & $\mathrm{E}_{1 / 2}$ red $(\mathrm{V})$ & $\mathrm{E}_{1 / 2} \mathrm{OX}(\mathrm{V})$ \\
\hline bpyC $_{12}$ 3a & 1 & $\begin{array}{l}+1.10 \\
+1.50\left(\mathrm{E}_{\mathrm{pa}}, \mathrm{irr}\right)\end{array}$ \\
\hline bpyCBP $\mathbf{3 b}$ & $-1.80\left(\mathrm{E}_{\mathrm{pc}}\right.$ irr. $)$ & - \\
\hline $\mathrm{Cl}_{2} \mathrm{Pt}\left(\mathrm{bpyC}_{12}\right) \mathbf{4 a}$ & $\begin{array}{l}-0.95 \\
-1.47\end{array}$ & +1.20 ( $\mathrm{E}_{\mathrm{pa}}$ irr. $)$ \\
\hline $\mathrm{Cl}_{2} \mathrm{Pt}(\mathrm{bpyCBP}) \mathbf{4 b}$ & $\begin{array}{l}-0.85 \\
-1.46\end{array}$ & / \\
\hline (dddt)Pt(bpyC 12 ) $\mathbf{1 a}$ & $\begin{array}{l}-1.08 \\
-1.62\end{array}$ & +1.10 (E $\mathrm{E}_{\mathrm{pa}}$ irr.) \\
\hline (dddt)Pt(bpyCBP) $\mathbf{1 b}$ & $\begin{array}{l}-1.01 \\
-1.60\end{array}$ & $\begin{array}{l}+0.26 \\
+0.98\end{array}$ \\
\hline $\begin{array}{l}\left(\mathrm{C}_{12} \mathrm{dt}\right) \mathrm{Pt}\left(\mathrm{bpyC}_{12}\right) \mathbf{2 a} \\
\left(\mathrm{C}_{12} \mathrm{dt}\right) \operatorname{Pt}(\mathrm{bpyCBP}) \mathbf{2} \mathbf{b}\end{array}$ & $\begin{array}{l}\text { Poorly soluble } \\
\text { Poorly soluble }\end{array}$ & \\
\hline (dddt)Pt(tBu $\left.{ }_{2} b p y\right) \mathbf{1 c}$ & -1.45 & $\begin{array}{l}+0.25 \\
+1.03\end{array}$ \\
\hline$\left(\mathrm{C}_{12} \mathrm{dt}\right) \operatorname{Pt}(\mathrm{bpy}) \mathbf{2 d}$ & -1.40 & $\begin{array}{l}+0.23 \\
+1.01 \text { ( } \mathrm{E}_{\mathrm{pa}} \text { irr.) }\end{array}$ \\
\hline
\end{tabular}

[a] Determined in $\mathrm{CH}_{2} \mathrm{Cl}_{2}+0.2 \mathrm{M} \mathrm{nBu}_{4} \mathrm{NPF}_{6}$ solution $\left(\mathrm{c} \sim 10^{-3} \mathrm{M}\right)$ at room temperature; scan rate, $100 \mathrm{mVs}^{-1}$. $\mathrm{E}_{1 / 2}=(\mathrm{Epa}+\mathrm{Epc}) / 2$; Epa and Epc are the anodic peak and the cathodic peak potentials, respectively. 


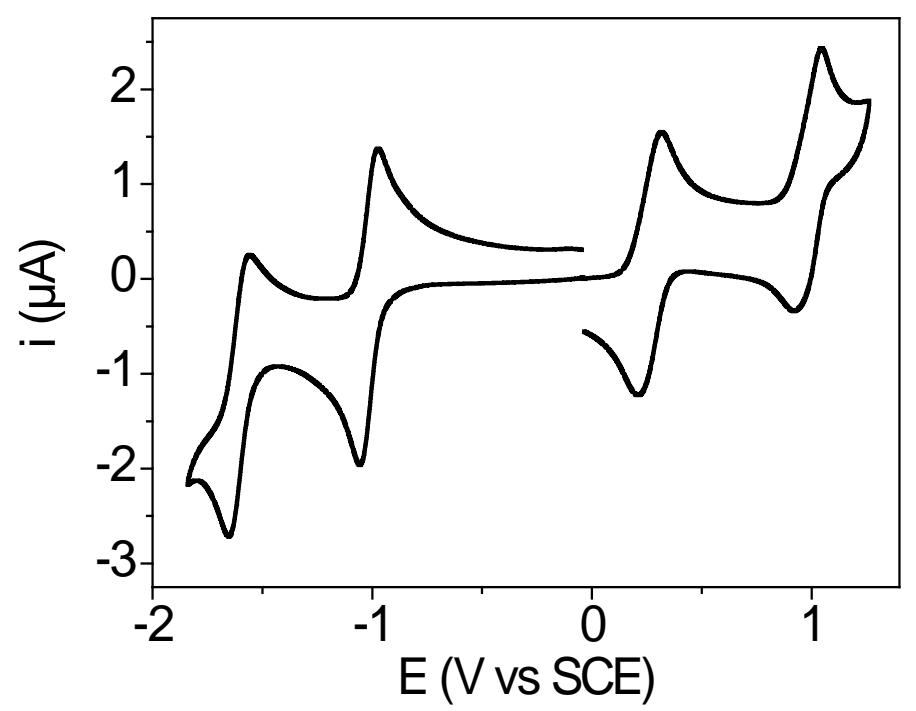

Figure 3. Cyclic voltammogram of (dddt)Pt(bpyCBP) $\mathbf{1 b}\left(\sim 10^{-3} \mathrm{M}\right)$ in $\mathrm{CH}_{2} \mathrm{Cl}_{2}$ containing 0.2 $\mathrm{M} \mathrm{NBu}_{4} \mathrm{PF}_{6}$ at a 1-mm disk carbon electrode. Scan rate is $0.1 \mathrm{~V} \mathrm{~s}^{-1}$ and $\mathrm{T}=293 \mathrm{~K}$.

\section{DFT calculations}

In order to get more insight into the electronic properties of the newly developed diiminedithiolene complexes, DFT geometry optimization of models of the complexes were carried out in vacuo. To optimize the computing time, the long carbon chains have been systematically replaced by methyl group, giving the corresponding $\mathbf{1} \mathbf{a}^{\prime}, \mathbf{1} \mathbf{b}^{\prime}, \mathbf{2} \mathbf{2}$ ' and $\mathbf{2} \mathbf{b}^{\prime}$ complexes. These calculations have also been conducted to estimate the energy levels and the nature of the redoxactive molecular orbitals of $\mathbf{2 a}$ and $\mathbf{2} \mathbf{b}$ since both these compounds are poorly soluble and not amenable to an electrochemical study. Figure 4 shows that all calculated compounds have a HOMO level comprised between -4.63 and -4.90 eV and a LUMO level between -3.17 and $3.48 \mathrm{eV}$. Specifically, the HOMO of 2a' (analog of insoluble 2a) is only $0.15 \mathrm{eV}$ higher than that of 1a' while its LUMO lies $0.17 \mathrm{eV}$ higher. Likewise the HOMO of $\mathbf{2} \mathbf{b}$ ' (analog of the insoluble $\mathbf{2 b}$ ) is also only $0.17 \mathrm{eV}$ higher than that of $\mathbf{1} \mathbf{b}^{\prime}$ while its LUMO lies $0.15 \mathrm{eV}$ higher. Taken together these results indicate that the oxidation potential of the $\mathrm{C}_{12} \mathrm{dt}$-ligated insoluble compounds $\mathbf{2 a}$ and $\mathbf{2 b}$ should be slightly higher and their reduction redox potentials slightly 
lower than their dddt-ligated congeners 1a and 1b. Examination of the nature of the frontier molecular orbitals of the calculated models (Figure 4) shows that the HOMOs of the Pt(II) diimine-dithiolene complexes is mainly centered on the bpy ligand with a metallic character while the LUMOs is mainly centered on the dithiolene ligand also with a metallic character. Hence, from these calculations, the lowest-energy transition between the frontier orbitals is best described as a mixed metal-ligand to mixed metal-ligand charge transfer (MMLMML'CT). The HOMO-LUMO gaps were computed for all the complexes at ca.1.45 eV in vacuo which would correspond to a low energy transition in the UV-visible-NIR spectra around $855 \mathrm{~nm}$.

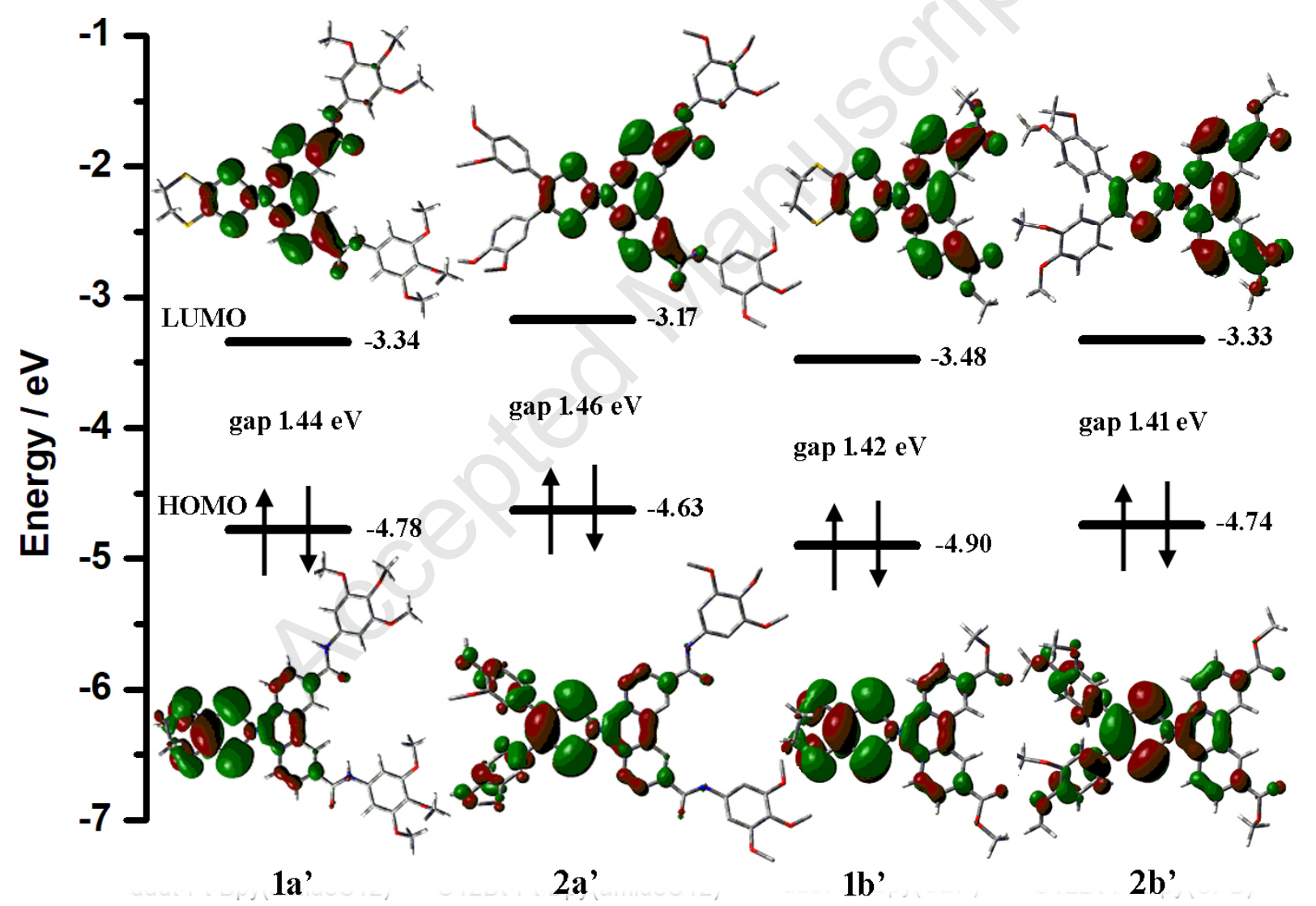

Figure 4. HOMO and LUMO frontier orbitals with energy levels (eV) of 1a', 2a', 1b' and $\mathbf{2} \mathbf{b}^{\prime}$ obtained by DFT B3LYP/LANL2DZ.

\section{Thermal and mesomorphic properties}


The thermal and mesomorphic properties of all the compounds carrying long carbon chains have been investigated by a combination of Polarized Optical Microscopy (POM), Differential Scanning Calorimetry (DSC) and Small Angle X-ray Scattering (SAXS). The transition temperatures, the enthalpies and the XRD results of all compounds are gathered in Table S5 and the thermal behaviors of the liquid crystalline compounds are summarized in the Scheme 3.

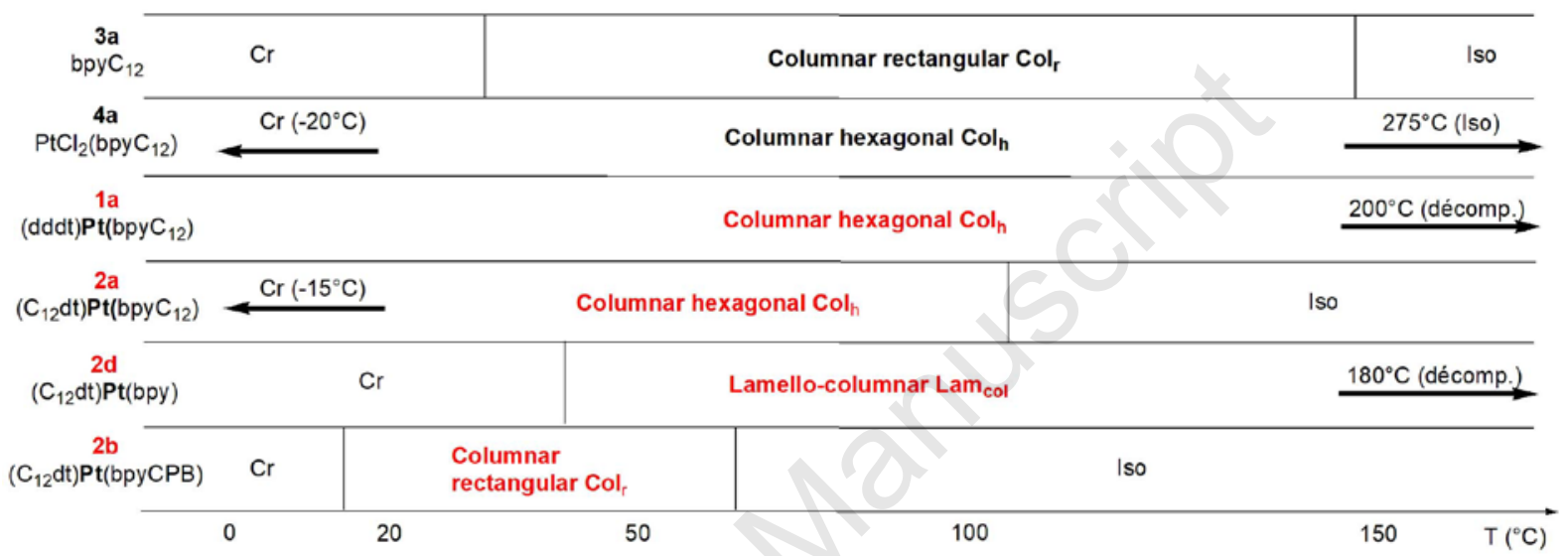

Scheme 3. Summary of the thermal behaviour of the liquid crystalline compounds.

The bpyC 12 ligand $3 a$ is in a mesomorphic state between 30 and $146{ }^{\circ} \mathrm{C}$ (Figure S16). On cooling from the isotropic state, a homogeneous and fluid texture develops between crosspolarizers (developable cylindrical domains) characteristic of a columnar phase (Figure S17). X-ray diffraction patterns recorded between 30 and $146{ }^{\circ} \mathrm{C}$ exhibit a series of sharp peaks in the small angle region that can be indexed as the reflections of a rectangular lattice $(a=54.9 \AA$, $\mathrm{b}=41.4 \AA$ at $140^{\circ} \mathrm{C}$ ) (Figure S18). In the wide angle region, a broad halo centered at $4.5 \AA$, associated to the mean distance between the alkyl chains in a molten state, confirms the liquid crystalline nature of the phase. An additional peak ( $\mathrm{h}_{\text {stack }}$ ) centered at $4.74 \AA$ is also observed and is attributed to the stacking distance between the bpyC ${ }_{12}$ 3a molecules along the column axis. Using a standard geometrical treatment, it is found that the rectangular unit cell $\mathrm{h}_{\text {stack-thick }}$ 
contains 4 molecules $\left(\mathrm{N}=\mathrm{S}_{\text {cell }} \mathrm{x} \mathrm{h}_{\text {stack }} / \mathrm{Vm}\right.$ with $\mathrm{V}_{\mathrm{m}}=\left(\mathrm{M}_{\mathrm{W}} / 0.6022\right) .{ }^{[27]}$ Based on $\mathrm{X}$-ray data, the size of the molecule and the number of molecules inserted inside the unit cell, a packing model can be proposed in which the bpyC $\mathrm{C}_{12}$ molecules are associated head to head to form a disc and the stacking of these dimeric discs leads to the formation of columns organized in the node of the rectangular lattice. FT-IR spectroscopic investigations performed on powder at room temperature show that the columnar organization is also stabilized by hydrogen bonding between the amide functionalities, as clearly evidenced by the $v_{\mathrm{NH}}$ and $v_{\mathrm{CO}}$ stretching vibrations observed respectively at 3246 and $1650 \mathrm{~cm}^{-1}$ (see experimental part). Note that corresponding values for the free amide are usually found at $3400 \mathrm{~cm}^{-1}$ for $v_{\mathrm{NH}}$ and around $1680 \mathrm{~cm}^{-1}$ for $v_{\mathrm{CO}} \cdot{ }^{[28]}$ The presence of single $v_{\mathrm{CO}}$ and $v_{\mathrm{NH}}$ stretching vibrations on the FTIR spectra also indicate the formation of a hydrogen bonded network involving all amide functionalities.

Interestingly, $\mathrm{PtCl}_{2}$ complexation of the free bipyridine ligand 3a strongly increases the thermal domain of the mesophase, from -20 to $+275^{\circ} \mathrm{C}$ (Figure S19). Above $275{ }^{\circ} \mathrm{C}$, the dichloroplatinum complex $\mathbf{4 a}$ is in an isotropic state and upon cooling, a fluid and birefringent texture with pseudo-fans shapes characteristic of columnar phases readily forms (Figure S20). Temperature-dependent XRD analyses confirm the existence of a columnar mesophase of hexagonal symmetry over the whole mesomorphic domain. The XRD patterns display in the small angle region four sharp peaks which can be unambiguously indexed as the 10, 21, 20 and 22 reflections of a 2D hexagonal lattice (Figure S21). The XRD pattern also displays a broad halo around $4.85 \AA$, indicative of the molten state of the alkyl chains. The hexagonal unit cell $\mathrm{h}_{\mathrm{ch}}$-thick contains 2 molecules and this also indicates that two molecules are associated inside the columnar stratums. The observation of a broad halo around $8.5 \AA$ (h'stack) corresponding to almost two times the $\mathrm{h}_{\mathrm{ch}}$ distance and of a broad halo around $3.5 \AA$ ( $\left.\mathrm{h}_{\text {stack }}\right)$ accounts for a headto-tail organization of the molecules mainly driven by $\pi-\pi$ stacking. No additional absorption or emission band associated to the presence of a metal-metal-to-ligand-charge-transfer state due 
to Pt-Pt interactions has been observed in solid state (Figure S6 and Figure S8). ${ }^{[29]}$ So, there is no evidence of the stabilization of the supramolecular arrangement through intermolecular PtPt interactions. Room temperature FT-IR measurements also confirm here $\left(v_{\mathrm{NH}}=3372 \mathrm{~cm}^{-1}\right.$ and $v_{\mathrm{CO}}=1672 \mathrm{~cm}^{-1}$, see experimental part) that the columnar organization of $\mathbf{4 a}$ is stabilized by hydrogen bonding between the amide functions of the ligand 3a.

DSC and POM investigations have shown that the dddt/bpyC ${ }_{12} \mathrm{Pt}$ complex 1a degrades above $200{ }^{\circ} \mathrm{C}$. No phase transition could be detected between $-25^{\circ} \mathrm{C}$ and $+200{ }^{\circ} \mathrm{C}$ (Figure S22). Between room temperature and $200{ }^{\circ} \mathrm{C}$, $\mathbf{1 a}$ appears as a birefringent and malleable soft material (Figure S23), which is a good indication that this compound is a liquid crystalline material. The SAXS patterns shows only one clear peak in the small angle region and no clear assignment can be done (Figure S24). However, in regard to the shape of the molecule and the previous results, it can be hypothesized that this compound is also likely organized into a columnar mesophase of hexagonal symmetry stabilized trough hydrogen bonding between the amide functionalities $\left(v_{\mathrm{NH}}=3326 \mathrm{~cm}^{-1}\right.$ and $\left.v_{\mathrm{CO}}=1676 \mathrm{~cm}^{-1}\right)$. With this hypothesis, the single observed reflection can be tentatively assigned as the (10) reflection of a 2D hexagonal lattice. It demonstrates however that the introduction of the dddt ligand strongly destabilizes the molecular organization inside the mesophase but the temperature range of existence of the mesophase is weakly affected. All these observations clearly highlight that this compound is also a liquid crystal.

Replacing the dddt ligand in $\mathbf{1 a}$ by the $\mathrm{C}_{12} \mathrm{dt}$ one gives $\mathbf{2 a}$ with long alkyl chains on both ligands. 2a is a birefringent soft material at room temperature. Upon heating, the viscosity of the compound decreases and the compound slowly become isotropic between $90{ }^{\circ} \mathrm{C}$ and 120 ${ }^{\circ} \mathrm{C}$. The DSC traces display no thermal transition at $100^{\circ} \mathrm{C}$, in line with a slow isotropization process extended over a large temperature range (Figure S25). Only a broad transition, associated to the slow crystallization of the carbon chains, is observed around $-15{ }^{\circ} \mathrm{C}$. 
Temperature-dependent XRD measurements confirm that the compound is isotropic above 100 ${ }^{\circ} \mathrm{C}$ with patterns displaying only broad halos in the whole $2 \theta$ range explored. Below $90^{\circ} \mathrm{C}$, the obtained diffractions patterns, with several sharp peaks in the small angle region and a broad peak around $20^{\circ}$ in $2 \theta$, clearly indicates that this compound is a liquid crystalline material (Figure 5). The four sharp peaks observed at low angles can unambiguously be indexed as the (10), (11), (20) and (21) reflections of a 2D lattice of hexagonal symmetry. The broad peak ( $\left.\mathrm{h}_{\mathrm{ch}}\right)$ at $4.5 \AA$ indicates that the carbon chains are in a molten state. Thus, this compound is organized from $-15{ }^{\circ} \mathrm{C}$ up to $90{ }^{\circ} \mathrm{C}$ into a columnar mesophase of hexagonal symmetry. The broad halo (h $\mathrm{h}_{\text {stack}}$ ) observed at $3.4 \AA$ is associated with short stacking along the column ( $\pi-\pi$ stacking). No evidence of Pt-Pt interactions has been detected by solid-state optical spectroscopy (Figure S6

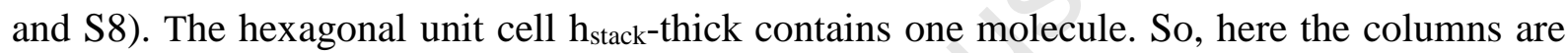
directly formed by a stacking of the disk-like molecules and the columns are then organized on the node of the 2D hexagonal cell with a parameter $a$ of $41.2 \AA$. To compensate the dipole moment and for a better space-filling, the molecule should adopt a head-to-tail arrangement along the columnar stacks (Figure 6).

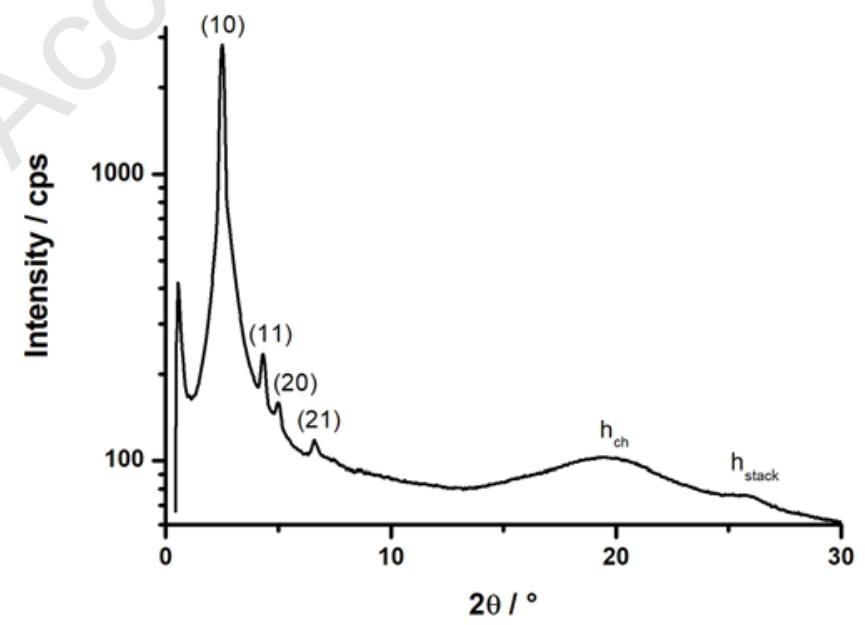

Figure 5. SAXS pattern of 2 a recorded at $70{ }^{\circ} \mathrm{C}\left(2^{\text {nd }}\right.$ heating $)$. 


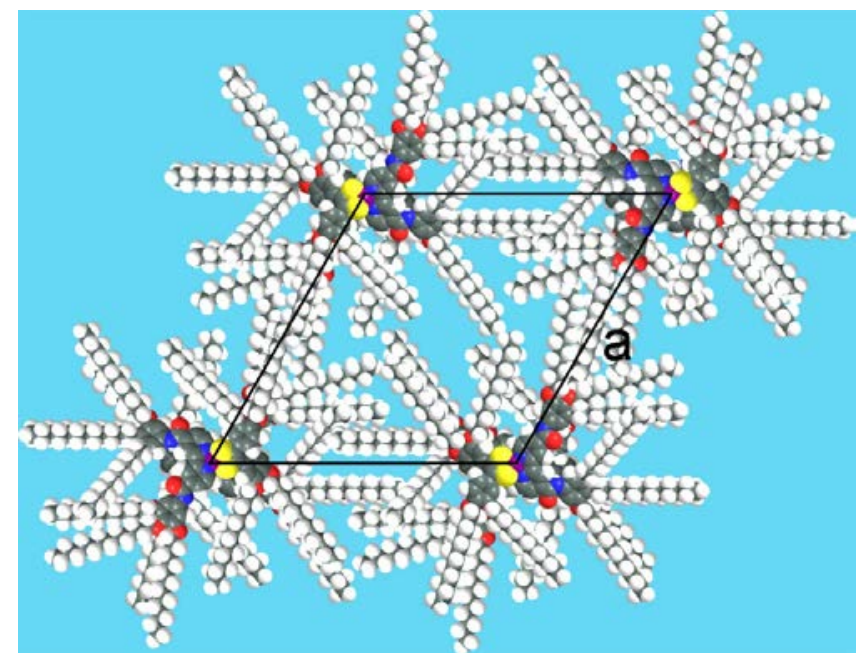

Figure 6. Proposed model for the organization of $\mathbf{2 a}$ in the $\mathrm{Col}_{\mathrm{h}}$ phase (Molecular diameter 48 Å (Dreiding model); atom: white = hydrogen, grey = carbon, blue = nitrogen, yellow $=$ sulfur, purple $=$ platinum, red $=$ oxygen $)$.

In conclusion, all the compounds incorporating the bpyC 12 ligand 3a, namely, 3a itself, 4a, 1a, and 2a were found to be liquid crystalline materials, highlighting that this novel ligand is a successful mesomorphic promotor of great interest to develop new metallomesogens.

DSC analyses, temperature-dependent XRD measurements and POM observations have revealed that the reference complex $\mathbf{2 d},\left(\mathrm{C}_{12} \mathrm{dt}\right) \mathrm{Pt}(\mathrm{bpy})$ is a liquid crystalline material from 42 ${ }^{\circ} \mathrm{C}$ up to the decomposition temperature around $180{ }^{\circ} \mathrm{C}$ (Figure S26 and S27). All the recorded XRD diffractograms (between 60 to $180^{\circ} \mathrm{C}$ ) are identical, and five sharp and intense smallangle reflections with reciprocal spacings in the ratios 1:2:3:4:5 are observed (Figure S28). These small-angle peaks are most readily assigned as the (001), (002), (003), (004) and (005) reflections of a lamellar phase with an interlayer spacing parameter $\mathrm{d}=32.2 \AA$ (at $\mathrm{T}=150{ }^{\circ} \mathrm{C}$, Table 3). In the wide angle region, a strong sharp peak is also observed at $3.46 \AA$ and is 
associated to a strong regular stacking of the molecule into columns. The SAXS patterns also displaying two additional small reflections at 9.01 and $4.375 \AA$ with reciprocal spacings in the ratio $1: 2$, which are associated to a lateral periodicity inside the plane. From the above XRD data, a model of organization can be proposed in which the molecules stack on top of each other to form columns with a periodicity of $3.46 \AA$ and these columns are then organized at a distance of $9 \AA$ into planes $32 \AA$ thick. This complex is organized into a lamello-columnar mesophase from $42{ }^{\circ} \mathrm{C}$ to $180{ }^{\circ} \mathrm{C}$. The proposed model in Figure S29 is in good agreement with the molecular dimensions but implies some interdigitations of the carbon chains (Figure S28). Below $42{ }^{\circ} \mathrm{C}$, the XRD patterns show several sharp peaks over the whole $2 \theta$ range and this confirms the crystallization of the compound at low temperatures.

Concerning the CBP series, the diimine ligand $\mathbf{3 b}$ is deprived of mesomorphic properties and this crystalline compound directly melts into an isotropic liquid around $140^{\circ} \mathrm{C}$ (Figure S30). Coordination with $\mathrm{PtCl}_{2}$ to give $\mathbf{4 b}$ did not allow for the emergence of liquid crystalline properties and only crystalline phases have been detected by SAXS. The DSC obtained with 4b, displaying endothermic and endothermic peaks on the heating curves, is indicative of strongly hindered crystallization processes (Figure S31). DSC analyses, POM observations and $\mathrm{X}$-ray analysis observations have revealed that the corresponding dddt complex $\mathbf{1 b}$ is a crystalline compound which decomposes above $180{ }^{\circ} \mathrm{C}$ (Figure S32). Finally, the introduction of the $\mathrm{C}_{12} \mathrm{dt}$ dithiolene ligand carrying long carbon chains confers liquid crystalline properties to the CBP series. The DSC traces of $\mathbf{2} \mathbf{b},\left(\mathrm{C}_{12} \mathrm{dt}\right) \mathrm{Pt}(\mathrm{bpyCBP})$, obtained upon heating display two broad endothermic transitions extending from -10 to $+40{ }^{\circ} \mathrm{C}$ and from $+70{ }^{\circ} \mathrm{C}$ to $+100{ }^{\circ} \mathrm{C}$ (Figure S33). Above $100{ }^{\circ} \mathrm{C}$, POM observations confirm that the complex is in an isotropic state. The high temperature transition undergoes a strong supercooling effect and a fluid and birefringent film readily forms below $45^{\circ} \mathrm{C}$, indicative of a liquid crystalline state that remains 
down to room temperature. No clear textural defect could have been developed, so no proper assignment of the phase symmetry can be done by POM. The low temperature transition is likely associated with slow crystallization of the complex. In the mesomorphic domains, the SAXS patterns displays several sharp peaks in the small angle region which can tentatively be indexed as the (11), (02), (22), (31) and (24) reflections of a rectangular lattice corresponding to the plane group C2mm $(\mathrm{h}+\mathrm{k}=2 \mathrm{n})\left(\mathrm{a}=42.8 \AA \mathrm{A}, \mathrm{b}=42.5 \AA\right.$ at $\left.30^{\circ} \mathrm{C}\right)$ (Figure 7). Two broad peaks are also observed in the wide angle region at 5.6 and 4.4 and are attributed to the mean distance between the CBP fragments and the carbon chains, respectively. ${ }^{[19]}$ A last broad peak is also observed at $3.4 \AA$ and is attributed to the stacking distance between the disk molecules. Applying the standard geometrical treatment, it is found that two molecules of $\mathbf{2} \mathbf{b}$ are contained inside a unit cell $h_{\text {stack }}$ thick, as expected for a rectangular cell. From the XRD data, an organization model can be proposed in which the molecules are stacked on top of each other to form columns and these columns are then organized on the two nodes of the 2D rectangular lattice (Figure 8). For a space filling, these dissymmetric disk-like molecules are certainly arranged head-to-tail with no obvious segregation between the cyanobiphenyl fragment and the carbon chains. To summarize, in the CBP series, only complex $\mathbf{2 b}$ forms a columnar mesophase of rectangular symmetry from 40 to $70{ }^{\circ} \mathrm{C}$ on heating and from 40 to $20^{\circ} \mathrm{C}$ upon cooling. With the CBP ligand, it is mandatory to introduce long carbon chains on the other side of the molecule (as in $\mathbf{2 b}$ ) to give it a disk-like shape able to organize into a mesophase. 


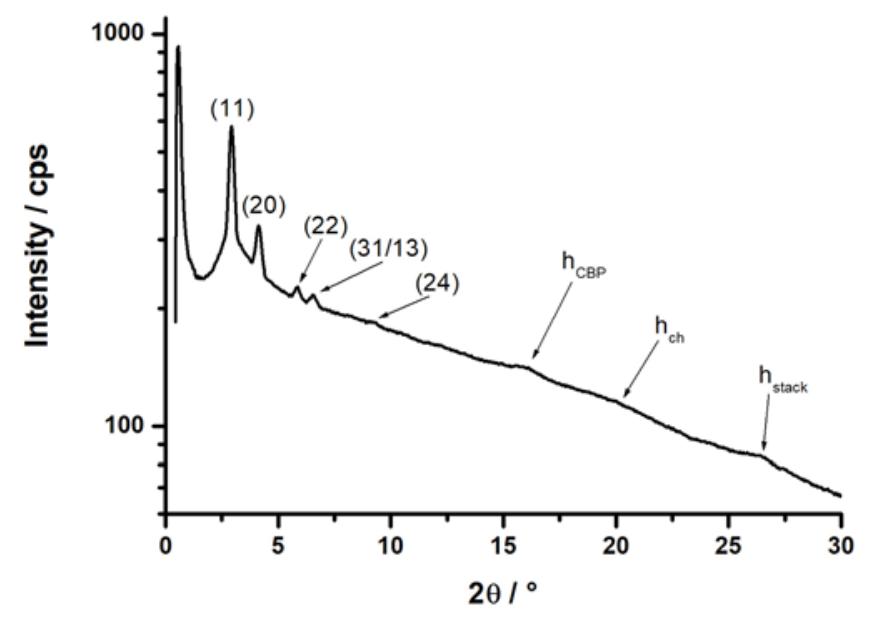

Figure 7. XRD pattern of $\mathbf{2 b},\left(\mathrm{C}_{12} \mathrm{dt}\right) \mathrm{Pt}(\mathrm{bpyCBP})$, recorded at $30{ }^{\circ} \mathrm{C}$ after cooling from the isotropic phase.

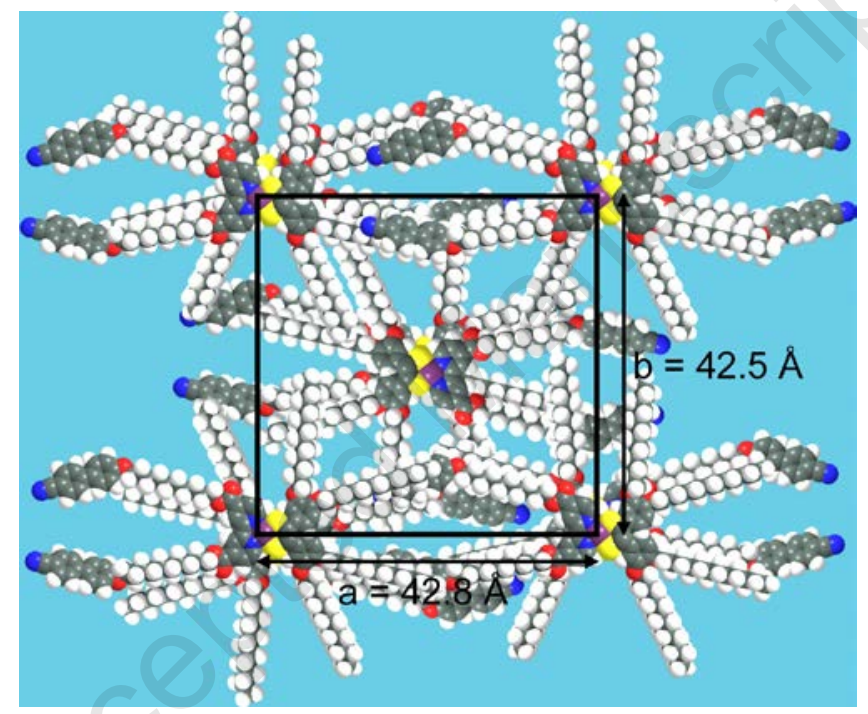

Figure 8. Proposed organization for $\mathbf{2 b}$ in the rectangular unit cell $h_{\text {stack }}$ thick $\left(h_{\text {stack }}=3.6 \AA\right)$ (extended length $\sim 53 \AA$ (Dreiding model); atom: white = hydrogen, grey = carbon, blue = nitrogen, yellow = sulfur, purple $=$ platinum, red = oxygen $)$.

In the bpyC12 series, all the compounds were found to be liquid crystalline materials with columnar mesophase of hexagonal or rectangular symmetry, meaning that bpyC12 ligand is a very good mesogenic promotor. On the contrary, with the bpyCBP ligand, liquid crystalline properties could be obtained provided that numerous long carbon chains were introduced on 
the dithiolate ligand to make the molecule more disk-shape and to counter-balance the stacking/crystallization of the cyanobiphenyl fragments.

\section{Conclusion}

Highly functional platinum diimine-dithiolene complexes have been isolated through an original synthetic route based on ligand metathesis. For this purpose, novel functional bipyridines carrying either tris-dodecyloxyphenyl fragments connected through an amide linker (bpyC ${ }_{12}$ ) or cyanobiphenyl fragments connected through ester linker carrying a C10 carbon chain (bpyCBP) have been developed. After coordination to $\mathrm{PtCl}_{2}$, the chlorine ligands have been successfully exchanged by dddt or $\mathrm{C}_{12} \mathrm{dt}$ dithiolene ligands directly from preformed tin or nickel dithiolene complexes. Thermal and X-ray analyses have revealed that, with the bpyC ${ }_{12}$ diimine ligand, columnar mesophase can be obtained over a large temperature range, showing that this ligand is a good mesogenic promoter. On the contrary, with the bpyCBP diimine ligand, it was mandatory to introduce numerous long carbon chains on the dithiolene fragment to observe the emergence of liquid crystalline properties. Inside the mesophase, the platinum diimine-dithiolene complexes are stacked in a head-to-tail fashion to form columns and these columns are then organized on the nodes of the 2D lattices or into lamellas. Charge transfer occurs from the electron donor dithiolate ligand to the electron acceptor bipyridine, as revealed the additional absorption band on the spectrum at low energy around 600-800 nm, depending on the nature of the ligands. The ambipolar character of these compounds was unambiguously confirmed by electrochemical investigation coupled to DFT calculations. In fact, the liquid crystalline platinum diimine-dithiolene complexes can be oxidized and reduced at easily accessible potentials. In particular, the platinum compound $\mathbf{2 d}$ with the dddt and the bpyC 12 ligands can clearly be reversibly oxidized or reduced and self-assembles into a lamellocolumnar phase over a large temperature range from $42{ }^{\circ} \mathrm{C}$ up to $180{ }^{\circ} \mathrm{C}$. Such ambipolar and 
liquid crystalline platinum diimine-dithiolene complexes are good candidates to develop new semiconducting soft materials and this work paves the way to develop new active layers in optoelectronic devices.

\section{Experimental part.}

$300\left({ }^{1} \mathrm{H}\right)$ and $75.5 \mathrm{MHz}\left({ }^{13} \mathrm{C}\right)$ NMR spectra were recorded on Bruker Avance 300 spectrometer at room temperature using perdeuterated solvents as internal standards. FT-IR spectra were recorded using a Bruker VERTEX 70 spectrometer equipped with an ATR apparatus. Elemental analyses were performed by the Service de Microanalyse, Institut de Chimie des Substances Naturelles, Gif sur Yvette, France. Mass spectra were recorded with a MALDI-TOF Microflex LT Bruker. UV-Vis spectra were recorded using a Cary 100 UV-Vis spectrophotometer (Varian). Photoluminescence spectra in solution were recorded with a Jobin-Yvon spectrofluorimeter. Quantum yields in solution ( $\phi$ sol) were calculated relative to $\left.\mathrm{Ru}(\mathrm{bpy})_{3}\right] \mathrm{Cl}_{2}$ ( $\phi=0.059$ in $\mathrm{CH}_{3} \mathrm{CN}$ ). $\phi$ sol was determined according to the following equation, $\phi$ sol $=\phi r e f \times 100 \times\left[\left(T_{s} \times A_{r}\right) /\left(T_{r} \times A_{s}\right)\right] \times\left[\left(n_{s} / n_{r}\right)^{2}\right]$

where, subscripts s and $\mathrm{r}$ refer respectively to the sample and reference. The integrated area of the emission peak in arbitrary units is given as $\mathrm{T}, \mathrm{n}$ is the refracting index of the solvent $(\mathrm{n}=$ 1.3404 for acetonitrile, $\mathrm{n}=1.4242$ for $\mathrm{CH}_{2} \mathrm{Cl}_{2}$ and $\mathrm{n}=1.4305$ for $\mathrm{DMF}$ ) and $\mathrm{A}$ is the absorbance.

Differential scanning calorimetry (DSC) was carried out by using NETZSCH DSC 200 F3 instrument equipped with an intracooler. DSC traces were measured at $10{ }^{\circ} \mathrm{C} / \mathrm{min}$ down to -25 ${ }^{\circ} \mathrm{C}$.

Optical microscopy investigations were performed on a Nikon H600L polarizing microscope equipped with a Linkam "liquid crystal pro system” hotstage LTS420. The microscope is also 
equipped with a UV irradiation source (Hg Lamp, $\lambda=340-380 \mathrm{~nm}$ ) and an ocean optic USB 2000+ UV-Vis-NIR spectrophotometer based on CCD detection technology.

X-ray scattering experiments (SAXS) were performed using a FR591 Bruker AXS rotating anode X-ray generator operated at $40 \mathrm{kV}$ and $40 \mathrm{~mA}$ with monochromatic $\mathrm{Cu} \mathrm{K} \alpha$ radiation ( $\lambda$ $=1.541 \AA$ ) and point collimation. The patterns were collected with a Mar345 Image-Plate detector (Marresearch, Norderstedt, Germany). The samples were held in Lindeman glass capillaries (1 mm diameter). The capillaries were placed inside a Linkam HFX350-Capillary X-Ray stage which allow measurements from $-196{ }^{\circ} \mathrm{C}$ up to $350{ }^{\circ} \mathrm{C}$ with an accuracy of $0.1^{\circ} \mathrm{C}$.

Cyclic voltammetry measurements were performed with a SP-50 biologic or a PGSTAT 302N (Eco-Chemie B.V.) potentiostat in a three-electrode glass cell. The working electrode was a 1 mm diameter glassy carbon disk and the counter electrode was a platinum wire. All reported potentials are referred to $\mathrm{KCl}$ Saturated Calomel Electrode (SCE) (uncertainty $\pm 5 \mathrm{mV}$ ). Tetran-butylammonium hexafluorophosphate $\mathrm{Bu}_{4} \mathrm{NPF}_{6}$ was purchased from Fluka (puriss, electrochemical grade) and was used, as received, at $0.2 \mathrm{~mol} \mathrm{~L}^{-1}$ as supporting electrolyte in anhydrous $\mathrm{CH}_{2} \mathrm{Cl}_{2}$. All electrochemical measurements were carried out inside a Faraday cage, at room temperature $\left(20 \pm 2{ }^{\circ} \mathrm{C}\right)$ and under constant argon flow. Prior to electrochemical analyses, the working electrode was carefully polished with diamond paste (Struers) onto a $1 \mu \mathrm{m}$ paper cloth (Struers) and thoroughly rinsed.

For the X-ray crystal structure of complex 1c, data were collected on an D8 VENTURE Bruker AXS diffractometer operating with graphite-monochromated Mo-K $\alpha$ radiation $(\lambda=0.71073 \AA)$. The structures was solved by direct methods using the SIR92 program ${ }^{[30]}$ and then refined with full-matrix least-square methods based on F2 (SHELXL-2014/7) ${ }^{[31]}$ with the aid of the WINGX 
program. ${ }^{[32]}$ All non-hydrogen atoms were refined with anisotropic atomic displacement parameters. All $\mathrm{H}$ atoms have been found in the electron density maps and refined in their idealized position using the AFIX instructions. Crystallographic data on X-ray data collection and structure refinements are given in Table S2-S6. Crystallographic data for structural analysis of the complex 1c has been deposited with the Cambridge Crystallographic Data Centre under CCDC 1867102. Copies of this information is available free of charge from the Web site (www.ccdc.cam.ac.uk).

Density Functional Theory ${ }^{[33]}$ calculations were performed with the hybrid Becke-3 parameter exchange functional ${ }^{[34]}$ and the Lee-Yang-Parr nonlocal correlation functional ${ }^{[35]}$ (B3LYP) implemented in the Gaussian 09 (Revision B.01) program suite ${ }^{[36]}$ using the pseudo-potentials LANL2DZ with the default convergence criteria implemented in the program. Calculations were carried out on the OCCIGEN calculator of the Centre Informatique National de l'Enseignement Supérieur (CINES (Montpellier) under project 2018-A0040805032). Figures were generated with GaussView 5.0.

\section{Synthesis.}

[2,2'-bipyridine]-4,4'-dicarboxylic acid ${ }^{[37]}, 3,4,5$-tris(dodecyloxy)aniline ${ }^{[38]}$ Bis[1,2bis(3',4'-di-n-dodecyloxyphenyl)ethane-1,2dithiolene]nickel $\quad$ (complex $\quad$ 6), ${ }^{[39]} \quad 4^{\prime}-[(10-$ bromodecyl)oxy]-4-carbonitrile-[1,1'-Biphenyl], ${ }^{[40]} \quad$ Dichloro(4,4'-di-ter/-butyl-2,2'bipyridine)platinum(II) $\quad\left(\left[\mathrm{PtCl}_{2}\left({ }^{\mathrm{t}} \mathrm{bu}_{2} \mathrm{bpy}\right)\right]\right) \quad($ complex $\quad 4 c),{ }^{[41]} \quad$ Dichloro(2,2'bipyridine)platinum(II) ([PtCl 2 (bpy)]) (complex 4d), ${ }^{[41]}$ 2,2-Dibutyl-5,6-dihydro-1,3,2dithiastannolo[4,5-b][1,4]dithiin (complex 5), ${ }^{[42]} \mathrm{PtCl}_{2}(\mathrm{DMSO})_{2}{ }^{[43]}$ were synthesized as 
previously described. All the other reagents were purchased from commercial sources and used as received. All synthetic manipulations were performed under an inert and dry nitrogen atmosphere using standard techniques. The reactions were followed by Thin Layer Chromatography (TLC) plates, revealed with a UV-lamp at $254 \mathrm{~nm}$ or iodine. Silica gel used in chromatographic separations was obtained from Acros Organics (Silica Gel, ultra-pure, 40$60 \mu \mathrm{m})$. Aluminium oxide 90 standardized from Merck KGaA was also used for chromatographic separations.

\section{Ligand 3a}

[2,2'-bipyridine]-4,4'-dicarboxylic acid (0.1 g, $0.4 \mathrm{mmol})$ was first refluxed overnight in $10 \mathrm{~mL}$ freshly distilled $\mathrm{SOCl}_{2}$ at $90{ }^{\circ} \mathrm{C}$ under $\mathrm{N}_{2}$ with 1 drop of $\mathrm{Et}_{3} \mathrm{~N}$. After removal of the excess $\mathrm{SOCl}_{2}$ and drying, the residue was dissolved in $20 \mathrm{~mL}$ of dry $\mathrm{CH}_{2} \mathrm{Cl}_{2}$ with 3,4,5tris(dodecyloxy)aniline (0.58 g, $0.9 \mathrm{mmol})$ and $\mathrm{Et}_{3} \mathrm{~N}(0.3 \mathrm{~mL}, 2.2 \mathrm{mmol})$ were added. The mixture was stirred at room temperature under $\mathrm{N}_{2}$ for $24 \mathrm{~h}$. The organic phase was washed with water (3x40 mL) and dried over $\mathrm{MgSO}_{4}$. The product was purified by column chromatography on alumina using a 50/50 petroleum ether/chloroform mixture as eluent. After recrystallization in a $\mathrm{CH}_{2} \mathrm{Cl}_{2} / \mathrm{MeOH}$ mixture, the product was isolated as a white powder in $40 \%$ yield $(0.25 \mathrm{~g})$. ${ }^{1} \mathrm{H}$ NMR (300 MHz, Chloroform-d) $\delta 8.86$ (d, $J=5.0 \mathrm{~Hz}, 2 \mathrm{H}, \mathrm{CH}_{\mathrm{bpy}}$ ), 8.77 (s, 2H, NH), 8.41 (s, 2H, $\mathrm{CH}_{\text {bpy }}$ ), 7.92 (d, J = 4.6 Hz, 2H, $\left.\mathrm{CH}_{\text {bpy }}\right), 7.00$ (s, 4H, CH), $4.17-3.84$ (m, 12H, $\mathrm{OCH}_{2}$ ), $1.90-1.54\left(\mathrm{~m}, 12 \mathrm{H}, \mathrm{CH}_{2}\right), 1.55-0.97\left(\mathrm{~m}, 108 \mathrm{H}, \mathrm{CH}_{2}\right), 0.95-0.80\left(\mathrm{~m}, 18 \mathrm{H}, \mathrm{CH}_{3}\right) .{ }^{13} \mathrm{C} \mathrm{NMR}$ (75 MHz, Chloroform- $d$ ) $\delta 163.48$ (Cq), 156.14 (Cq), 153.43 (Cq), 150.47 (CH), 143.58 (Cq), $135.66(\mathrm{Cq}), 132.94(\mathrm{Cq}), 122.55(\mathrm{CH}), 117.53(\mathrm{CH}), 99.53(\mathrm{CH}), 73.72\left(\mathrm{OCH}_{2}\right), 69.34$ $\left(\mathrm{OCH}_{2}\right), 32.11\left(\mathrm{CH}_{2}\right), 32.09\left(\mathrm{CH}_{2}\right), 30.47\left(\mathrm{CH}_{2}\right), 29.93\left(\mathrm{CH}_{2}\right), 29.91\left(\mathrm{CH}_{2}\right), 29.87\left(\mathrm{CH}_{2}\right), 29.82$ (CH$), 29.80\left(\mathrm{CH}_{2}\right), 29.60\left(\mathrm{CH}_{2}\right), 29.56\left(\mathrm{CH}_{2}\right), 29.53\left(\mathrm{CH}_{2}\right), 26.31\left(\mathrm{CH}_{2}\right), 26.27\left(\mathrm{CH}_{2}\right), 22.85$ ( $\left.\mathrm{CH}_{2}\right), 14.27\left(\mathrm{CH}_{3}\right)$. IR-ATR ( $\left.\mathrm{cm}^{-1}\right)$ : $3246(v \mathrm{NH}), 3064$ (vCH), $2916(v \mathrm{CH}), 2851(\mathrm{vCH}), 1650$ 
$(v \mathrm{C}=\mathrm{O}), 1602(v \mathrm{C}=\mathrm{C}), 1539(\delta \mathrm{NH}), 1507(v \mathrm{C}=\mathrm{C}), 1464\left(\delta \mathrm{CH}_{2}\right), 1426\left(\delta \mathrm{CH}_{2}\right), 1386\left(\delta \mathrm{CH}_{3}\right)$, 1312 (vC-N), 1232, 1119, 1066, 997, 954, 911, 853, 812,712, 657, 614, 517. UV-vis UV-vis $\left[\mathrm{CH}_{2} \mathrm{Cl}_{2}, \lambda_{\max }(\mathrm{nm})\left(\varepsilon\left(\mathrm{M}^{-1} \cdot \mathrm{cm}^{-1}\right)\right)\right]: 298$ (22500). MALDI-TOF-MS: $m / z=1500.5\left(\mathrm{M}^{+}\right)$. Anal. Calc. for $\mathrm{C}_{96} \mathrm{H}_{162} \mathrm{~N}_{4} \mathrm{O}_{8}$ (\%): C 76.85, H 10.88, N 3.73. Found (\%): C 76.60, H 10.98, N 3.52.

\section{Ligand 3b}

[2,2'-Bipyridine]-4,4'-dicarboxylic acid (0.12 g, $0.5 \mathrm{mmol})$ was first refluxed overnight in 10 $\mathrm{mL}$ freshly distilled $\mathrm{SOCl}_{2}$ at $90{ }^{\circ} \mathrm{C}$ under $\mathrm{N}_{2}$. After removal of the excess $\mathrm{SOCl}_{2}$ by distillation and drying, the residue was dissolved in $20 \mathrm{~mL}$ of dry $\mathrm{CH}_{2} \mathrm{Cl}_{2}$ together with $4^{\prime}-[(10-$ bromodecyl)oxy]-4-carbonitrile-[1,1'-Biphenyl] (0.3 g, 0.9 mmol). Et $3 \mathrm{~N}$ (0.3 mL, $2.2 \mathrm{mmol})$ was added and the reaction mixture was stirred at room temperature for 3 days. After removal of the solvent, the residue was purified by column chromatography on alumina gel using a gradient of eluents for pure $\mathrm{CH}_{2} \mathrm{Cl}_{2}$ to $\mathrm{CH}_{2} \mathrm{Cl}_{2}+1 \% \mathrm{v} / \mathrm{v} \mathrm{MeOH}$. The product was isolated as a white powder in $56 \%$ yield $(0.25 \mathrm{~g})$.

${ }^{1} \mathrm{H}$ NMR (300 MHz, Chloroform-d) $\delta 8.95$ (s, 2H, CH $\mathrm{bpy}_{\text {) }}$ ), 8.86 (d, $J=5.0 \mathrm{~Hz}, 2 \mathrm{H}, \mathrm{CH}_{\mathrm{bpy}}$ ), 7.89 (dd, $J=5.0,1.6 \mathrm{~Hz}, 2 \mathrm{H}, \mathrm{CH}_{\mathrm{bpy}}$ ), $7.74-7.59$ (m, 8H, $\mathrm{CH}_{\text {biph }}$ ), $7.57-7.43$ (m, 4H, $\mathrm{CH}_{\text {biph }}$ ), 7.09 - 6.88 (m, 4H, CHbiph), 4.39 (t, $\left.J=6.8 \mathrm{~Hz}, 4 \mathrm{H}, \mathrm{OCH}_{2}\right), 4.00$ (t, $\left.J=6.5 \mathrm{~Hz}, 4 \mathrm{H}, \mathrm{OCH}_{2}\right), 1.96-$ $1.70\left(\mathrm{~m}, 8 \mathrm{H}, \mathrm{CH}_{2}\right), 1.69-1.18\left(\mathrm{~m}, 24 \mathrm{H}, \mathrm{CH}_{2}\right) .{ }^{13} \mathrm{C}$ NMR $(75 \mathrm{MHz}$, Chloroform-d) $\delta 165.34$ (Cq), 159.94 (Cq), 156.67 (Cq), 150.22 (CH), 145.42 (Cq), 139.17 (Cq), 132.69 (CH), 131.41 (Cq), $128.45(\mathrm{CH}), 127.20(\mathrm{CH}), 123.37(\mathrm{CH}), 120.71(\mathrm{CH}), 119.23(\mathrm{Cq}), 115.23(\mathrm{CH}), 110.20$ (Cq), $68.30\left(\mathrm{OCH}_{2}\right), 66.18\left(\mathrm{OCH}_{2}\right), 29.59\left(\mathrm{CH}_{2}\right), 29.55\left(\mathrm{CH}_{2}\right), 29.47\left(\mathrm{CH}_{2}\right), 29.35\left(\mathrm{CH}_{2}\right), 28.76$ ( $\left.\mathrm{CH}_{2}\right), 26.16\left(\mathrm{CH}_{2}\right), 26.06\left(\mathrm{CH}_{2}\right)$. IR-ATR $\left(\mathrm{cm}^{-1}\right)$ : 3065 (vCH), $2918(v \mathrm{CH}), 2850(v \mathrm{CH}), 2221$ (vCN), $1725(v \mathrm{C}=\mathrm{O}), 1600(v \mathrm{C}=\mathrm{C}), 1554,1530,1494(v \mathrm{C}=\mathrm{C}), 1467\left(\delta \mathrm{CH}_{2}\right), 1428\left(\delta \mathrm{CH}_{2}\right)$, 1394, 1366, 1314, 1289, 1270 , 1252, 1176, 1133, 1117, 1063, 1042, 1028, 1011, 997, 950, 920, 854, 823, 808, 768, 724, 693, 665, 616, 583, 563, 531, 510, 472, 424, 407. UV-vis [CH $\mathrm{CH}_{2}$, 
$\left.\lambda_{\max }(\mathrm{nm})\left(\varepsilon\left(\mathrm{M}^{-1} . \mathrm{cm}^{-1}\right)\right)\right]: 298(55900)$. MALDI-TOF-MS: $\mathrm{m} / \mathrm{z}=911.8\left(\mathrm{M}^{+}\right)$. Anal. Calc. for $\mathrm{C}_{58} \mathrm{H}_{62} \mathrm{~N}_{4} \mathrm{O}_{6}, \mathrm{CH}_{3} \mathrm{OH}$ (\%): C 75.13, H 7.05, N 5.94. Found (\%): C 75.68, H 6.83, N 5.72.

\section{Complex 4a}

Ligand 3a (0.1g, $0.07 \mathrm{mmol})$ was dissolved in $10 \mathrm{~mL}$ dry THF in a Schlenk flask with 1 eq. of $\mathrm{PtCl}_{2}(\mathrm{DMSO})_{2}(0.028 \mathrm{~g}, 0.07 \mathrm{mmol})$ and the reaction mixture was then heated at $60{ }^{\circ} \mathrm{C}$ for $24 \mathrm{~h}$. After removal of the solvent, the product was purified by column chromatography on alumina gel using chloroform as eluent. After recrystallization in a $\mathrm{CH}_{2} \mathrm{Cl}_{2} / \mathrm{MeOH}$ solvent mixture, the product was isolated as an orange powder in $76 \%$ yield $(0.09 \mathrm{~g})$.

${ }^{1} \mathrm{H}$ NMR (300 MHz, Chloroform-d) $\delta 9.38$ (s, 4H, NH/CH $\mathrm{Cpy}_{\text {) }}$ ) 8.47 (s, 2H, $\mathrm{CH}_{\text {bpy }}$ ), 7.88 (s, 2H, $\mathrm{CH}_{\text {bpy }}$ ), 7.11 (s, 4H, $\left.\mathrm{CH}_{\mathrm{ph}}\right), 4.17-3.65$ (m, 12H, $\left.\mathrm{OCH}_{2}\right), 1.88-1.59$ (m, 12H, $\left.\mathrm{CH}_{2}\right), 1.55$ $1.08\left(\mathrm{~m}, 108 \mathrm{H}, \mathrm{CH}_{2}\right), 1.02-0.74\left(\mathrm{~m}, 18 \mathrm{H}, \mathrm{CH}_{3}\right) .{ }^{13} \mathrm{C}$ NMR (75 MHz, Chloroform-d) $\delta 162.17$ (Cq), $156.44(\mathrm{Cq}), 153.22(\mathrm{Cq}), 149.38(\mathrm{CH}), 135.60(\mathrm{Cq}), 133.78(\mathrm{Cq}), 133.26(\mathrm{Cq}), 122.21$ (CH), $107.62(\mathrm{CH}), 99.60(\mathrm{CH}), 73.84\left(\mathrm{OCH}_{2}\right), 69.27\left(\mathrm{OCH}_{2}\right), 32.10\left(\mathrm{CH}_{2}\right), 30.53\left(\mathrm{CH}_{2}\right), 30.00$ (CH$), 29.97\left(\mathrm{CH}_{2}\right), 29.94\left(\mathrm{CH}_{2}\right), 29.91\left(\mathrm{CH}_{2}\right), 29.88\left(\mathrm{CH}_{2}\right), 29.76\left(\mathrm{CH}_{2}\right), 29.62\left(\mathrm{CH}_{2}\right), 29.57$ (CH$), 26.38\left(\mathrm{CH}_{2}\right), 26.34\left(\mathrm{CH}_{2}\right), 22.85\left(\mathrm{CH}_{2}\right), 14.25\left(\mathrm{CH}_{3}\right)$. IR-ATR $\left(\mathrm{cm}^{-1}\right)$ : $3372(\mathrm{vNH}), 3075$ (vCH) , $2921(v \mathrm{CH}), 2852(v \mathrm{CH}), 1672\left(v^{\mathrm{C}}=\mathrm{O}\right), 1606(v \mathrm{C}=\mathrm{C}), 1538(\delta \mathrm{NH}), 1505(\mathrm{vC}=\mathrm{C})$, 1467( $\left.\delta \mathrm{CH}_{2}\right), 1421\left(\delta \mathrm{CH}_{2}\right), 1383\left(\delta \mathrm{CH}_{3}\right), 1347\left(\delta \mathrm{CH}_{3}\right), 1307$ (vC-N), 1259, 1231, 1174, 1113, 1017, 908, 835, 814, 754, 721, 702, 662, 626, 589, 415.UV-vis $\left[\mathrm{CH}_{2} \mathrm{Cl}_{2}, \lambda\right.$ max $(\mathrm{nm})\left(\varepsilon\left(\mathrm{M}^{-1} . \mathrm{cm}^{-}\right.\right.$ $\left.{ }^{1}\right)$ )]: 412 (9300), 320 (19100), 292 (28300). MALDI-TOF-MS: $m / z=1728.5\left(\mathrm{M}^{+}-\mathrm{Cl}\right)$. Anal. Calc. for $\mathrm{C}_{96} \mathrm{H}_{162} \mathrm{Cl}_{2} \mathrm{~N}_{4} \mathrm{O} 8 \mathrm{Pt}, 0.5 \mathrm{CH}_{2} \mathrm{Cl}_{2}$ (\%): C 64.08, H 9.08, N 3.10. Found (\%): C 63.79, H 8.83, N 2.90.

\section{Complex 4b}


Ligand 3b (0.18 g, $0.2 \mathrm{mmol})$ was dissolved in $10 \mathrm{~mL}$ dry THF in a Schlenk flask with 1 eq. of $\mathrm{PtCl}_{2}$ (DMSO) 2 (0.08 g, $\left.0.2 \mathrm{mmol}\right)$ and the reaction mixture was then heated at $60{ }^{\circ} \mathrm{C}$ for $48 \mathrm{~h}$. After removal of the solvent and purification by column chromatography on alumina gel using $\mathrm{CH}_{2} \mathrm{Cl}_{2}$ as eluent, the product was isolated as a yellow powder in $52 \%$ yield $(0.12 \mathrm{~g})$.

${ }^{1} \mathrm{H}$ NMR (300 MHz, Chloroform-d) $\delta 9.94$ (dd, $J=6.0,0.6 \mathrm{~Hz}, 2 \mathrm{H}, \mathrm{CH}_{\mathrm{bpy}}$ ), 8.58 (d, $J=1.4 \mathrm{~Hz}$, 2H, $\mathrm{CH}_{\text {bpy }}$ ), 8.08 (dd, $J=6.0,1.8 \mathrm{~Hz}, 2 \mathrm{H}, \mathrm{CH}_{\text {bpy }}$ ), $7.72-7.59$ (m, 8H, $\mathrm{CH}_{\text {biph }}$ ), 7.52 (dd, $J=$ 8.8, 3.0 Hz, 4H, CHbiph), $7.02-6.93$ (m, 4H, $\mathrm{CH}_{\text {biph }}$ ), 4.47 (t, $J=6.8 \mathrm{~Hz}, 4 \mathrm{H}, \mathrm{OCH}_{2}$ ), 4.00 (td, $\left.J=6.5,1.5 \mathrm{~Hz}, 4 \mathrm{H}, \mathrm{OCH}_{2}\right), 1.93-1.74\left(\mathrm{~m}, 8 \mathrm{H}, \mathrm{CH}_{2}\right), 1.66-1.22\left(\mathrm{~m}, 24 \mathrm{H}, \mathrm{CH}_{2}\right) .{ }^{13} \mathrm{C} \mathrm{NMR}$ (75 MHz, Chloroform-d) $\delta 163.11$ (Cq), 159.92 (Cq), 157.34 (Cq), 145.35 (CH), 140.55 (Cq), 132.71 (CH), $131.42(\mathrm{Cq}), 128.46(\mathrm{CH}), 127.20(\mathrm{CH}), 122.97(\mathrm{CH}), 121.41(\mathrm{CH}), 119.24(\mathrm{Cq})$, $115.23(\mathrm{CH}), 110.24(\mathrm{Cq}), 68.32\left(\mathrm{OCH}_{2}\right), 67.58\left(\mathrm{OCH}_{2}\right), 29.55\left(\mathrm{CH}_{2}\right), 29.33\left(\mathrm{CH}_{2}\right), 28.66$ ( $\left.\mathrm{CH}_{2}\right), 26.20\left(\mathrm{CH}_{2}\right), 26.02\left(\mathrm{CH}_{2}\right)$. IR-ATR $\left(\mathrm{cm}^{-1}\right)$ : $3071(v \mathrm{CH}), 2925(v \mathrm{CH}), 2852(v \mathrm{CH}), 2223$ (vCN), $1729(v \mathrm{C}=\mathrm{O}), 1601(\mathrm{vC}=\mathrm{C}), 1580,1554,1524,1494(v \mathrm{C}=\mathrm{C}), 1472\left(\delta \mathrm{CH}_{2}\right), 1413$ $\left(\delta \mathrm{CH}_{2}\right), 1289,1248,1180,1142,1116,1062,1031,1013,999,959,905,874,855,821,805$, 762, 729, 708, 661, 564, 531, 421. UV-vis $\left[\mathrm{CH}_{2} \mathrm{Cl}_{2}, \lambda \max (\mathrm{nm}), \varepsilon\left(\mathrm{M}^{-1} \cdot \mathrm{cm}^{-1}\right)\right]: 429(7020), 300$ (105200). MALDI-TOF-MS: $m / z=1140.8\left(\mathrm{M}^{+}-\mathrm{Cl}\right)$. Anal. Calc. for $\mathrm{C}_{58} \mathrm{H}_{62} \mathrm{Cl}_{2} \mathrm{~N}_{4} \mathrm{O}_{6} \mathrm{Pt}, \mathrm{C}_{7} \mathrm{H}_{8}$ (\%): C 61.51, H 5.56, N 4.41. Found (\%): C 61.75, H 5.91, N 4.23.

\section{Complex 1a}

Complex 4a (0.05 g, $0.03 \mathrm{mmol})$ and one equivalent of 2,2-Dibutyl-5,6-dihydro-1,3,2dithiastannolo[4,5-b][1,4]dithiin $(0.012 \mathrm{~g}, 0.03 \mathrm{mmol})$ were dissolved in $5 \mathrm{~mL}$ acetone and 1 $\mathrm{mL}$ THF. The mixture was stirred at room temperature under air for 3 days. The green precipitate, which has formed, was filtered, washed with acetone and dried. The product was recrystallized by slow evaporation of $\mathrm{CH}_{2} \mathrm{Cl}_{2}$ from a $\mathrm{CH}_{2} \mathrm{Cl}_{2} / \mathrm{CH}_{3} \mathrm{CN}$ solvent mixture. After filtration and drying, the product was isolated as a green powder is $75 \%$ yield $(0.04 \mathrm{~g})$. 
${ }^{1} \mathrm{H}$ NMR (300 MHz, Chloroform-d) $\delta 10.02$ (s, 2H, NH), 9.13 (s, 2H, CHbpy), 7.70 (s, 2H, $\mathrm{CH}_{\text {bpy }}$ ), 7.26 (s, 4H, CH $\mathrm{ph}_{\text {) }}, 6.88$ (d, $J=6.3 \mathrm{~Hz}, 2 \mathrm{H}, \mathrm{CH}_{\text {bpy }}$ ), $4.28-3.51$ (m, 16H, $\mathrm{SCH}_{2} / \mathrm{OCH}_{2}$ ), $2.07-1.65\left(\mathrm{~m}, 12 \mathrm{H}, \mathrm{CH}_{2}\right), 1.65-0.99\left(\mathrm{~m}, 108 \mathrm{H}, \mathrm{CH}_{2}\right), 1.06-0.73\left(\mathrm{~m}, 18 \mathrm{H}, \mathrm{CH}_{3}\right) .{ }^{13} \mathrm{C} \mathrm{NMR}$ (75 MHz, Chloroform-d) $\delta 164.22(\mathrm{Cq}), 153.22(\mathrm{Cq}), 147.13(\mathrm{Cq}), 134.03(\mathrm{Cq}), 120.18(\mathrm{Cq})$, $103.03(\mathrm{Cq}), 100.22(\mathrm{CH}), 73.80\left(\mathrm{OCH}_{2}\right), 69.34\left(\mathrm{OCH}_{2}\right), 32.37\left(\mathrm{CH}_{2}\right), 30.87\left(\mathrm{CH}_{2}\right), 30.22$ $\left(\mathrm{CH}_{2}\right), 30.12\left(\mathrm{CH}_{2}\right), 29.82\left(\mathrm{CH}_{2}\right), 26.72\left(\mathrm{CH}_{2}\right), 23.08\left(\mathrm{CH}_{2}\right), 14.27\left(\mathrm{CH}_{3}\right)$. All the aromatic peaks are not visible on the ${ }^{13} \mathrm{C}$ NMR spectrum. IR-ATR $\left(\mathrm{cm}^{-1}\right): 3326(v \mathrm{~N}-\mathrm{H}), 3073(\mathrm{vCH})$, $2920(v \mathrm{CH}), 2852(v \mathrm{CH}), 1676(v \mathrm{C}=\mathrm{O}), 1606(v \mathrm{C}=\mathrm{C}), 1546(\mathrm{NH}), 1504(v \mathrm{C}=\mathrm{C}), 1467\left(\delta \mathrm{CH}_{2}\right)$, $1427\left(\delta \mathrm{CH}_{2}\right), 1381\left(\delta \mathrm{CH}_{3}\right), 1346\left(\delta \mathrm{CH}_{3}\right), 1308(v \mathrm{C}-\mathrm{N}), 1259,1232,1113,1016,912,806$, 754, 721, 669, 624, 582. UV-vis UV-vis $\left[\mathrm{CH}_{2} \mathrm{Cl}_{2}, \lambda_{\max }(\mathrm{nm})\left(\varepsilon\left(\mathrm{M}^{-1} \cdot \mathrm{cm}^{-1}\right)\right)\right]: 414(9060), 316$ (23400). MALDI-TOF-MS: $m / z=1874.5\left(\mathrm{M}^{+}\right)$. Anal. Calc. for $\mathrm{C}_{100} \mathrm{H}_{166} \mathrm{~N}_{4} \mathrm{O}_{8} \mathrm{PtS}_{4}$ (\%): C 64.03, H 8.92, N 2.99. Found (\%): C 63.64, H 9.28, N 3.01.

\section{Complex 1c}

$100 \mathrm{mg}$ of $\left[\mathrm{PtCl}_{2}\right.$ ('bu ${ }_{2}$ bpy)] were dissolved with one equivalent of 2,2-Dibutyl-5,6-dihydro1,3,2-dithiastannolo[4,5-b][1,4]dithiin (0.012 g, $0.03 \mathrm{mmol})$ in $10 \mathrm{~mL}$ acetone. The solution was stirring at room temperature under $\mathrm{N}_{2}$ during $20 \mathrm{~h}$. After evaporation of the solvent, the product was purified by column chromatography on silica gel using a gradient of solvent from pure petroleum ether to pure $\mathrm{CH}_{2} \mathrm{Cl}_{2}$. The blue product was dissolved in $\mathrm{CHCl}_{3}$ and recrystallized by slow diffusion of pentane. $65 \mathrm{mg}$ of dark-blue crystals, suitable for XRD analysis, have been isolated (54 \% yield).

${ }^{1} \mathrm{H}$ NMR (300 MHz, Chloroform- $d$ ) $\delta 8.92$ (d, $J=6.1 \mathrm{~Hz}, 2 \mathrm{H}, \mathrm{CH}_{\mathrm{bpy}}$ ), 7.90 (d, $J=2.0 \mathrm{~Hz}, 2 \mathrm{H}$, $\mathrm{CH}_{\text {bpy }}$ ), 7.39 (dd, $J=6.1,2.0 \mathrm{~Hz}, 2 \mathrm{H}, \mathrm{CH}_{\mathrm{bpy}}$ ), 3.03 (s, 4H, $\mathrm{SCH}_{2}$ ), 1.44 (s, $\left.18 \mathrm{H}, \mathrm{CH}_{3}\right) .{ }^{13} \mathrm{C} \mathrm{NMR}$ (75 MHz, Chloroform- $d$ ) $\delta 162.84(\mathrm{Cq}), 155.62(\mathrm{Cq}), 148.35(\mathrm{CH}), 124.89(\mathrm{CH}), 119.70(\mathrm{CH})$, $35.90(\mathrm{Cq}), 30.45\left(\mathrm{CH}_{2}\right), 30.35\left(\mathrm{CH}_{3}\right)$. IR-ATR $\left(\mathrm{cm}^{-1}\right)$ : $3074(v \mathrm{CH}), 2953(v \mathrm{CH}), 2905(v \mathrm{CH})$, 
$2865(v \mathrm{CH}), 1615(v \mathrm{C}=\mathrm{C}), 1539,1485(v \mathrm{C}=\mathrm{C}), 1462\left(\delta \mathrm{CH}_{2}\right), 1414,1394\left(\delta \mathrm{CH}_{3}\right), 1365$ ( $\left.\mathrm{vCH}_{3}\right), 1283,1265,1251,1202,1154,1123,1076,1030,973,926,903,869,850,826,772$, 733, 688, 672, 593, 564, 532, 481, 442, 416. UV-vis $\left[\mathrm{CH}_{2} \mathrm{Cl}_{2}, \lambda_{\max }(\mathrm{nm})\left(\varepsilon\left(\mathrm{M}^{-1} . \mathrm{cm}^{-1}\right)\right)\right]: 635$ (9,318 x 103), 380 (7510), 300 (65200). MALDI-TOF-MS: $m / z=643.3\left(\mathrm{M}^{+}\right)$Anal. Calc. for $\mathrm{C}_{22} \mathrm{H}_{28} \mathrm{~N}_{2} \mathrm{PtS}_{4}$ (\%): C 41.04, H 4.38, N 4.35. Found (\%): C 41.05, H 4.53, N 4.27

\section{Complex 2d}

First, $\left[\mathrm{PtCl}_{2}\right.$ (bpy)] (0.048 g, $\left.0.11 \mathrm{mmol}\right)$ was reacted with 2.2 eq. of silver triflate $(0.064 \mathrm{~g}, 0.25$ mmol) in $5 \mathrm{~mL}$ of dry $\mathrm{CH}_{3} \mathrm{CN}$ under $\mathrm{N}_{2}$ atmosphere for $4 \mathrm{~h}$. The suspension was filtered over celite to remove the formed silver chloride salt. After removal of the solvent, the residue was redissolved in $10 \mathrm{~mL}$ dry THF and 0.5 eq. of complex 6 were added $(0.114$ g, $0.055 \mathrm{mmol})$. The mixture was heated at reflux under $\mathrm{N}_{2}$ for 3 days. After evaporation of the solvent, the product was purified by flash column chromatography on silica gel using a gradient of eluents for pure $\mathrm{CH}_{2} \mathrm{Cl}_{2}$ to $\mathrm{CH}_{2} \mathrm{Cl}_{2}+5 \% \mathrm{v} / \mathrm{v} \mathrm{MeOH}$. After removal of the solvents, the product was isolated as a blue powder in $28 \%$ yield (43 mg).

${ }^{1} \mathrm{H}$ NMR (300 MHz, Chloroform-d) $\delta 9.30$ (s, 2H, $\mathrm{CH}_{\mathrm{bpy}}$ ), $7.99-7.84$ (m, 4H, $\mathrm{CH}_{\mathrm{bpy}} / \mathrm{CH}_{\mathrm{ph}}$ ), $7.42-7.28$ (m, 4H, $\left.\mathrm{CH}_{\text {bpy }} / \mathrm{CH}_{\mathrm{ph}}\right), 6.83-6.65$ (m, 4H, $\left.\mathrm{CH}_{\text {bpy }} / \mathrm{CH}_{\mathrm{ph}}\right), 4.40-4.19$ (m, 8H, $\left.\mathrm{OCH}_{2}\right)$, $2.11-1.89\left(\mathrm{~m}, 8 \mathrm{H}, \mathrm{CH}_{2}\right), 1.73-1.12\left(\mathrm{~m}, 72 \mathrm{H}, \mathrm{CH}_{2}\right), 1.05-0.73\left(\mathrm{~m}, 12 \mathrm{H}, \mathrm{CH}_{3}\right) .{ }^{13} \mathrm{C} \mathrm{NMR}$ (75 MHz, Chloroform-d) $\delta$ 31.99, 29.84, 29.81, 29.79, 29.76, 29.70, 29.45, 29.37, 26.53, 26.35, $22.73,14.09,0.99$. Only the peaks of the carbon chains are visible at high concentration on the ${ }^{13}$ C NMR spectra. IR-ATR $\left(\mathrm{cm}^{-1}\right): 3081$ (vCH), 2955 (vCH), 2917 (vCH), 2850 (vCH), 1605 $(v \mathrm{C}=\mathrm{C}), 1540,1497(v \mathrm{C}=\mathrm{C}), 1469\left(\delta \mathrm{CH}_{2}\right), 1449\left(\delta \mathrm{CH}_{2}\right), 1431\left(\delta \mathrm{CH}_{2}\right), 1414,1382\left(\delta \mathrm{CH}_{3}\right)$, 1313, 1257, 1237, 1182, 1131, 1068, 1031, 995, 958, 905, 842, 809, 787, 746, 716, 654, 629, 607, 413. UV-vis $\left[\mathrm{CH}_{2} \mathrm{Cl}_{2}, \lambda_{\max }(\mathrm{nm})\left(\varepsilon\left(\mathrm{M}^{-1} . \mathrm{cm}^{-1}\right)\right)\right]: 660$ (11020), 348 (34500), 304 (91900), 270 (117300), 254 (138800). MALDI-TOF-MS: $\mathrm{m} / \mathrm{z}=1329.4\left(\mathrm{M}^{+}\right)$. Anal. Calc. for 
$\mathrm{C}_{72} \mathrm{H}_{114} \mathrm{~N}_{2} \mathrm{O}_{4} \mathrm{PtS}_{2}, 0.2 \mathrm{CH}_{2} \mathrm{Cl}_{2}$ (\%): C 64.34, H 8.55, N 2.08 S 4.76. Found (\%): C 64.45, H 8.76, N 1.83 S 4.81.

\section{Complex 1b}

Complex 4b (0.09 g, $0.07 \mathrm{mmol})$ were dissolved in $10 \mathrm{~mL}$ acetone with $5 \mathrm{~mL}$ THF and one equivalent of of 2,2-Dibutyl-5,6-dihydro-1,3,2-dithiastannolo[4,5-b][1,4]dithiin (0.032 g, 0.07 mmol) was added. The reaction mixture was stirred at room temperature under $\mathrm{N}_{2}$ atmosphere. After 3 days, the green precipitate, which has formed, was filtered, washed with acetone and dried. The compound was next dissolved in $\mathrm{CH}_{2} \mathrm{Cl}_{2}$, filtered over celite to remove the insoluble and recrystallized in $\mathrm{CH}_{3} \mathrm{CN}$. The compound was isolated as a green powder in $63 \%$ yield (62 mg).

${ }^{1} \mathrm{H}$ NMR (300 MHz, Chloroform-d) $\delta 9.75$ (d, $J=6.0 \mathrm{~Hz}, 2 \mathrm{H}, \mathrm{CH}_{\mathrm{bpy}}$ ), 8.57 (d, $J=1.8 \mathrm{~Hz}, 2 \mathrm{H}$, $\mathrm{CH}_{\text {bpy }}$ ), 8.04 (dd, $J=6.0,1.7 \mathrm{~Hz}, 2 \mathrm{H}, \mathrm{CH}_{\text {bpy }}$ ), $7.73-7.56$ (m, 8H, $\left.\mathrm{CH}_{\text {biph }}\right), 7.54-7.45$ (m, 4H, CH biph), $7.01-6.92$ (m, 4H, $\mathrm{CH}_{\text {biph }}$ ), 4.46 (t, $J=6.8 \mathrm{~Hz}, 4 \mathrm{H}, \mathrm{OCH}_{2}$ ), 3.99 (t, $J=6.5 \mathrm{~Hz}, 4 \mathrm{H}$,

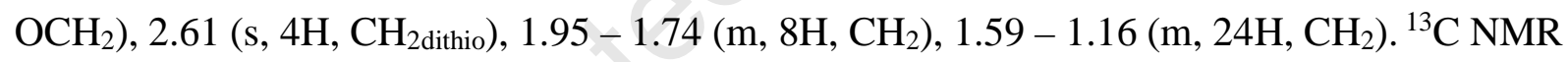
(75 MHz, Chloroform-d) $\delta 163.13$ (Cq), 159.89 (Cq), 157.49 (Cq), 150.30 (CH), 145.31 (Cq), $140.50(\mathrm{Cq}), 132.68(\mathrm{CH}), 131.33(\mathrm{Cq}), 128.42(\mathrm{CH}), 127.15(\mathrm{CH}), 126.92(\mathrm{CH}), 123.22(\mathrm{CH})$, 119.20 (Cq), $115.20(\mathrm{CH}), 110.15(\mathrm{Cq}), 68.28\left(\mathrm{OCH}_{2}\right), 67.48\left(\mathrm{OCH}_{2}\right), 41.12(\mathrm{Cq}), 32.91\left(\mathrm{CH}_{2}\right)$, $29.82\left(\mathrm{CH}_{2}\right), 29.57\left(\mathrm{CH}_{2}\right), 29.53\left(\mathrm{CH}_{2}\right), 29.47\left(\mathrm{CH}_{2}\right), 29.35\left(\mathrm{CH}_{2}\right), 29.32\left(\mathrm{CH}_{2}\right), 28.64\left(\mathrm{CH}_{2}\right)$, 26.16 $\left(\mathrm{CH}_{2}\right), 25.99\left(\mathrm{CH}_{2}\right), 22.81\left(\mathrm{CH}_{2}\right)$. IR-ATR $\left(\mathrm{cm}^{-1}\right)$ : $3070(v \mathrm{CH}), 2923(v \mathrm{CH}), 2853(\mathrm{vCH})$, $2224(v \mathrm{CN}), 1723(v \mathrm{C}=\mathrm{O}), 1602(v \mathrm{C}=\mathrm{C}), 1580,1494(v \mathrm{C}=\mathrm{C}), 1469(\delta \mathrm{CH} 2), 1433\left(\delta \mathrm{CH}_{2}\right)$, 1409, $1321\left(\delta \mathrm{CH}_{3}\right), 1292,1249,1180,1131,1032,999,958,852,821,758,723,703,661,562$, 531, 414. UV-vis $\left[\mathrm{CH}_{2} \mathrm{Cl}_{2}, \lambda_{\max }(\mathrm{nm})\left(\varepsilon\left(\mathrm{M}^{-1} \cdot \mathrm{cm}^{-1}\right)\right)\right]: 808$ (7540), 528 (2425), 440 (2690), 377 (5320), 300 (61230). MALDI-TOF-MS: $m / z=1285.4\left(\mathrm{M}^{+}\right)$. Anal. Calc. for $\mathrm{C}_{62} \mathrm{H}_{66} \mathrm{~N}_{4} \mathrm{O}_{6} \mathrm{PtS}_{4}$, $0.5 \mathrm{CH}_{2} \mathrm{Cl}_{2}$ (\%): C 56.48, H 5.08, N 4.22, S 9.65. Found (\%): C 56.11, H 5.02, N 4.17 S 9.48. 


\section{Complex 2a}

Complex 4a (0.055 g, $0.03 \mathrm{mmol})$ was reacted with 2.2 eq. of silver triflate $(0.018 \mathrm{~g}, 0.07 \mathrm{mmol})$ in $10 \mathrm{~mL}$ of dry THF under $\mathrm{N}_{2}$ atmosphere for $24 \mathrm{~h}$. The suspension was filtered over celite to remove the formed silver chloride salt. 0.5 eq. of complex 6 ( $0.03 \mathrm{~g}, 0.015 \mathrm{mmol})$ were then added to the filtrate and the mixture was heated at reflux under $\mathrm{N}_{2}$ for $60 \mathrm{~h}$. After evaporation of the solvent, the product was purified by flash column chromatography on silica gel using $\mathrm{CH}_{2} \mathrm{Cl}_{2}+1 \% \mathrm{v} / \mathrm{v} \mathrm{MeOH}$ as eluent. After drying, the product was isolated as a green powder in $43 \%$ yield (36 mg).

Despite several attempts $\left(\mathrm{CDCl}_{3}, \mathrm{~d}_{6}-\mathrm{DMSO}, \mathrm{CD}_{2} \mathrm{Cl}_{2}\right)$, no clear ${ }^{1} \mathrm{H}$ and ${ }^{13} \mathrm{C}$ NMR spectra has been obtained for this compound. IR-ATR $\left(\mathrm{cm}^{-1}\right)$ : $3072(v \mathrm{CH}), 2956(v \mathrm{CH}), 2921(v \mathrm{CH}), 2852$ (vCH), $1725(v \mathrm{C}=\mathrm{O}), 1667(v \mathrm{C}=\mathrm{O}), 1603(v \mathrm{C}=\mathrm{C}), 1546(\delta \mathrm{NH}), 1505(v \mathrm{C}=\mathrm{C}), 1466\left(\delta \mathrm{CH}_{2}\right)$, 1429, $1379\left(\delta \mathrm{CH}_{3}\right), 1262,1115,1074,1019,802,731 . \mathrm{UV}$-vis $\left[\mathrm{CH}_{2} \mathrm{Cl}_{2}, \lambda \max (\mathrm{nm})\left(\varepsilon\left(\mathrm{M}^{-1} . \mathrm{cm}^{-}\right.\right.\right.$ 1))]: 626 (6910), 430 (16830), 306 (72740). MALDI-TOF-MS: $m / z=2674.2\left(\mathrm{M}^{+}\right)$. Anal. Calc. for $\mathrm{C}_{158} \mathrm{H}_{268} \mathrm{~N}_{4} \mathrm{O}_{12} \mathrm{PtS}_{2}, 2 \mathrm{CH}_{2} \mathrm{Cl}_{2}$ (\%): C 67.55, H 9.64, N 1.97, S 2.25. Found (\%): C 67.62, H 9.22, N 1.76, S 2.39.

\section{Complex 2b}

$25 \mathrm{mg}$ of complex $\mathbf{4 b}(0.02 \mathrm{mmol})$ were reacted with 2.2 eq. of silver triflate in $5 \mathrm{~mL}$ of $\mathrm{CH}_{3} \mathrm{CN}$ under $\mathrm{N}_{2}$ atmosphere for $17 \mathrm{~h}$. The solution was filtered over celite and 0.5 eq. of complex 6 ( $0.021 \mathrm{~g}, 0.01 \mathrm{mmol})$ were then added to the filtrate and the mixture was heated at reflux under $\mathrm{N}_{2}$ for $48 \mathrm{~h}$. After evaporation of the solvent, the product was purified by column chromatography on silica gel using a gradient of eluent from $\mathrm{CH}_{2} \mathrm{Cl}_{2}+1 \% \mathrm{v} / \mathrm{v}$ THF to $\mathrm{CH}_{2} \mathrm{Cl}_{2}+$ $5 \% \mathrm{v} / \mathrm{v}$ THF. The product was isolated as a blue compound in $42 \%$ yield (18.5 mg). 
Despite several attempts $\left(\mathrm{CDCl}_{3}, \mathrm{~d}_{6}-\mathrm{DMSO}, \mathrm{CD}_{2} \mathrm{Cl}_{2}\right)$, no clear ${ }^{1} \mathrm{H}$ and ${ }^{13} \mathrm{C}$ NMR spectra has been obtained for this compound. IR-ATR $\left(\mathrm{cm}^{-1}\right)$ : 3076 (vCH), $2920(\mathrm{vCH}), 2851(\mathrm{vCH}), 2225$ (vCN), $1724(v \mathrm{C}=\mathrm{O}), 1603(v \mathrm{C}=\mathrm{C}), 1581,1509,1495(v \mathrm{C}=\mathrm{C}), 1467\left(\delta \mathrm{CH}_{2}\right), 1429\left(\delta \mathrm{CH}_{2}\right)$, 1413, $1381\left(\mathrm{\delta CH}_{3}\right), 1261,1246,1180,1138,1117,1063,1030,927,896,850,804,759,730$, 706, 661, 636, 606, 563, 531. UV-vis $\left[\mathrm{CH}_{2} \mathrm{Cl}_{2}, \lambda_{\max }(\mathrm{nm})\left(\varepsilon\left(\mathrm{M}^{-1} \cdot \mathrm{cm}^{-1}\right)\right)\right]: 816(12880), 298$ (216050). MALDI-TOF-MS: $m / z=2085.19\left(\mathrm{M}^{+}\right)$. Anal. Calc. for $\mathrm{C}_{120} \mathrm{H}_{168} \mathrm{~N}_{4} \mathrm{O}_{10} \mathrm{PtS}_{2}, 2 / 3$ $\mathrm{CH}_{2} \mathrm{Cl}_{2}$ (\%): C 67.65, H 7.97, N 2.62, S 2.99. Found (\%): C 67.70, H 8.60, N 1.90 S 2.60.

Keywords: Platinum diimine dithiolene $\bullet$ Coordination chemistry $\bullet$ Liquid crystal

- Ambipolar • Charge transfer

\section{Acknowledgements.}

The CNRS, Rennes Metropole and the University of Rennes 1 are gratefully acknowledged for financial support. This work was granted access to the high performance computing resources of CINES (Montpellier, France) under allocation 2018-A0040805032 awarded by GENCI. Antoine Vacher is gratefully acknowledged for his help in the solid-state absorption measurements.

Supporting Information description. UV-vis-NIR absorption spectra, emission spectra and cyclic voltammograms of all the compounds as well as additional DSC, POM and X-rays analyses. CCDC 1867102 contains the supplementary crystallographic data for complex 1c. These data can be obtained free of charge from The Cambridge Crystallographic Data Centre via www.ccdc.cam.ac.uk/data_request/cif.

TOC. 


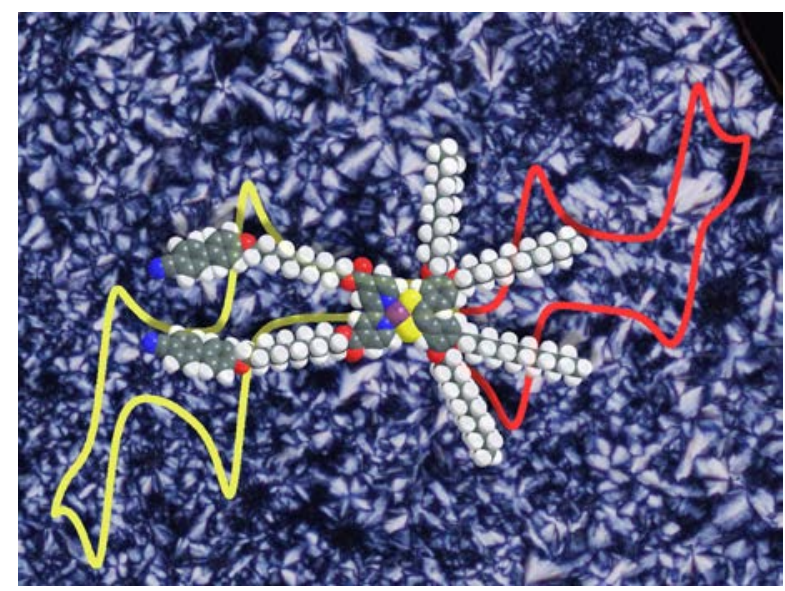

Highly functional mesogens constructed around ambipolar platinum diimine-dithiolene cores

have been isolated through an original ligand metathesis approach.

\section{References.}

[1] a) T. Wöhrle, I. Wurzbach, J. Kirres, A. Kostidou, N. Kapernaum, J. Litterscheidt, J.C. Haenle, P. Staffeld, A. Baro, F. Giesselmann, S. Laschat, Chem Rev. 2016, 116, 1139-1241; b) S. Kumar, CRC Press, Boca Raton, USA, 2011; c) S. Setia, S. Sidiq, J. De, I. Pani, S.K. Pal, Liq Cryst. 2016, 43, 2009-2050; d) R.K. Gupta, V. Manjuladevi, C. Karthik, K. Choudhary, Liq Cryst. 2016, 43, 2079-2091; e) S.M. Said, M.S. Mahmood, M.N. Daud, M.F. Mohd Sabri, N.A. Sairi, Liq Cryst. 2016, 43, 2092-2113.

[2] a) H. Iino, J. Hanna, Opto-Electron. Rev. 2005, 13, 295-302; b) S. Sergeyev, W. Pisula, Y. H. Geerts, Chem. Soc. Rev. 2007, 36, 1902-1929; c) M. Funahashi, Polym. J. 2009, 41, 459-469.

[3] A) H. Iino, J. Hanna, opto-electronics review 2005, 13, 295-302; b) H. Monobe , Y. Shimizu, S. Okamoto, H. Enomoto, Mol. Cryst. Liq. Cryst. 2007, 476, 31/[277]-41/[287].

[4] T. Yasuda, T. Shimizu, F. Liu, G. Ungar, T. Kato, J. Am. Chem. Soc. 2011, 133, 13437-13444.

[5] (a) G. Bottari, G. de la Torres, D.M. Guldi, T. Torres, Chem. Rev. 2010, 110, 6768-6816; (b) A. de la Escosura, M.V. Martinez-Diaz, J. Barbera, T. Torres, J. Org. Chem. 2008, 73, 1475-1480; (c) Y.H. Geerts, O. Debever, C. Amato, S. Sergeyev, Beilstein J. Org. Chem. 2009, 5, DOI:10.3762/bjoc.5.49; (d) M. Ince, M.V. Martinez-Diaz, J. Barbera, T. Torres, J. Mater. Chem. 2011, 21, 1531-1536.

[6] P. Samorì, A. Fechtenkötter, E. Reuther, M. Watson, N. Severin, K. Müllen, J. Rabe, Adv. Mater. 2006, 18, 1317-1321.

[7] X. Liu, T. Usui, J. Hanna, Chem. Mater. 2014, 26, 5437-5440.

[8] T. Kushida, A. Shuto, M. Yoshio, T. Kato, S. Yamaguchi, Angew. Chem. Int. Ed. 2015, 54, 6922-6925.

[9] Seema Barard, Theo Kreouzis, Andrew N Cammidge, Michael J Cook, Asim K Ray, Semicond. Sci. Technol. 2018, 33, 095010.

[10] H. Hayashi, W. Nihashi, T. Umeyama, Y. Matano, S. Seki, Y. Shimizu, H. Imahori, J. Am. Chem. Soc. 2011, 133, 10736-10739.

[11] H. Geng, K. Luo, G. Zou, L. Zhao, H. Wang, Q. Li, H. Ni, Dyes and Pigments 2018, 149, 82-91.

[12] a) T. Kusamoto, S. Kume, H. Nishihara, J. Am. Chem. Soc. 2008, 130, 13844-13845; b) W. Liu, R. Wang, X.-H. Zhou, J.-L. Zuo, X.-Z. You, Organometallics 2008, 27, 126-134.

[13] a) W. Paw, S.D. Cummings, M. Adnan Mansour, W.B. Connick, D.K. Geiger, R. Eisenberg, Coord. Chem. Rev. 1998, 171, 125-150; b) S.D. Cummings, R. Eisenberg, Inorg. Chem. 1995, 34, 2007-2014; c) J.A. Zuleta, C.A. Chesta, R. Eisenberg, J. Am. Chem. Soc. 1989, 111, 8916-8917; d) J.A. Zuleta, J.M. Bevilacqua, D.M. Proserpio, P.D. Harvey, R. Eisenberg, Inorg. Chem. 1992, 31, 12, 2396-2404.

[14] a) J. Zhang, P. Du, J. Schneider, P. Jarosz, R. Eisenberg, J. Am. Chem. Soc. 2007, 129, 7726-7727 ; b) G. Li, M. F. Mark, H. Lv, D.W. McCamant, R. Eisenberg, J. Am. Chem. Soc. 2018, 140, 2575-2586. 
[15] a) B.W. Smucker, J.M. Hudson, M.A. Omary, K.R. Dunbar, Inorg. Chem. 2003, 42, 4714-4723; b) K. Diwan, R. Chauhan, S.K. Singh, B. Singh, M.G. B. Drew, L. Bahadura, N. Singh, New J. Chem. 2014, 38, 97-108.

[16] a) Y. Ji, R. Zhang, X.-B. Du, J.-L. Zuo, X.-Z. You, Dalton Trans. 2008, 2578-2582; b) Y. Ji, R. Zhang, Y.-J. Li, Y.-Z. Li, J.-L. Zuo, X.-Z. You, Inorg. Chem. 2007, 46, 866-873.

[17] H.-C. Chang, K. Komasaka, K. Kishida, T. Shiozaki, T. Ohmori, T. Matsumoto, A. Kobayashi, M. Kato, S. Kitagawa, Inorg. Chem. 2011, 50, 4279-4288.

[18] C.E. Whittle, J.A. Weinstein, M.W. George, K.S. Schanze, Inorg. Chem. 2001, 40, 4053-4062.

[19] B. Huitorel, Q. Benito, A. Fargues, A. Garcia, T. Gacoin, J.-P. boilot, S. Perruchas, F. Camerel, Chem. Mater. 2016, 28, 8190-8200.

[20] a) C.-W. Chan, L.-K. Cheng, C.-M. Che, Coord. Chem. Rev. 1994, 132, 87-97; b) T.J. Wadas, R.J. Lachicotte, R. Eisenberg, Inorg. Chem. 2003, 42, 3772-3778; c) V.M. Miskowski, V.H. Houlding, C.-M. Che, Y. Wang, Inorg. Chem. 1993, 32, 2518-2524.

[21] a) S.D. Cummings, R. Eisenberg, J. Am. Chem. Soc. 1996, 118, 1949-1960; b) W.B. Connick, H.B. Gray, J. Am. Chem. Soc.1997, 119, 11620-11627.

[22] K. Nakamaru, Bull. Chem. Soc. Jpn 1982, 55, 1639-1640.

[23] S. Campidelli, J. Lenoble, J. Barbera, F. Paolucci, M. Marcaccio, D. Paolucci, R. Deschenaux, Macromolecules 2005, 38, 7915-7925;

[24] A. Gennaro, A.A. Isse, J.-M. Savéant, M.G. Severin, E. Vianello, J. Am. Chem. Soc. 1996, 118, 7190-7196

[25] E.J.L. McInnes, R.D. Farley, C.C. Rowlands, A.J. Welch, L. Rovatti, L.J. Yellowlees, J. Chem. Soc., Dalton Trans., 1999, 4203-4208;

[26] Y. Misaki, Y. Tani, K. Takahashi, K. Tanaka, Molecular Crystals and Liquid Crystals (2002), 379, 71-76.

[27] F. Camerel, F. Kinloch, O. Jeannin, M. Robin, S. K. Nayak, E. Jacques, K. A. Brylev, N. G. Naumov, Y. Molard, Dalton Trans., 2018, 47, 10884-10896.

[28] S. Debnath, H. F. Srour, B. Donnio, Marc Fourmigué, F. Camerel, RSC Adv. 2012, 2, 4453-4462.

[29] F. Camerel, R. Ziessel, B. Donnio, C. Bourgogne, D. Guillon, M. Schmutz, C. Iacovita, J.-P. Bucher, Angew. Chem. Int. Ed., 2007, 46, 2659-2662

[30] A. Altomare, G. Cascarano, C. Giacovazzo, A. Guagliardi, M. C. Burla, G. Polidori, M. Camalli, J. Appl. Cryst. 1994, 27, 435.

[31] G. M Sheldrick, Acta Cryst. C 2015, 71, 3-8.

[32] L.J.J. Farrugia, Appl. Cryst. 2012, 45, 849-854.

[33] a) P. Hohenberg and W. Kohn, Phys. Rev. 1964, 136, B864-B871; b) R.G. Parr, W. Yang, Density-Functional Theory of Atoms and Molecules; Oxford University Press: Oxford, U.K., 1989.

[34] a) A. D. Becke, Phys. Rev. A 1988, 38, 3098-3100; b) A. D. Becke, J. Chem. Phys. 1993, 98, 1372-1377; c) A. D. Becke, J. Chem. Phys. 1993, 98, 5648-5652.

[35] C. Lee, W. Yang, R. G. Parr, Phys. Rev. B 1988, 37, 785-789.

[36] M. J. Frisch, G. W. Trucks, H. B. Schlegel, G. E. Scuseria, M. A. Robb, J. R. Cheeseman, G. Scalmani, V. Barone, B. Mennucci, G. A. Petersson, H. Nakatsuji, M. Caricato, X. Li, H. P. Hratchian, A. F. Izmaylov, J. Bloino, G. Zheng, J. L. Sonnenberg, M. Hada, M. Ehara, K. Toyota, R. Fukuda, J. Hasegawa, M. Ishida, T. Nakajima, Y. Honda, O. Kitao, H. Nakai, T. Vreven, J. A. J. Montgomery, J. E. Peralta, F. Ogliaro, M. Bearpark, J. J. Heyd, E. Brothers, K. N. Kudin, V. N. Staroverov, T. Keith, R. Kobayashi, J. Normand, K. Raghavachari, A. Rendell, J. C. Burant, S. S. Iyengar, J. Tomasi, M. Cossi, N. Rega, J. M. Millam, M. Klene, J. E. Knox, J. B. Cross, V. Bakken, C. Adamo, J. Jaramillo, R. Gomperts, R. E. Stratmann, O. Yazyev, A. J. Austin, R. Cammi, C. Pomelli, J. W. Ochterski, R. L. Martin, K. Morokuma, V. G. Zakrzewski, G. A. Voth, P. Salvador, J. J. Dannenberg, S. Dapprich, A. D. Daniels, O. Farkas, J. B. Foresman, J. V. Ortiz, J. Cioslowski, D. J. Fox, Gaussian 09, Revision B.01, Gaussian, Inc., Wallingford CT, 2010.

[37] J. Bai, H. Wei, B Li, L. Song, L. Fang, Z. Lv, W. Zhou, E. Wang, Chem. Asian J. 2008, 3, 1935-1941.

[38] C.V. Yelamaggad, A.S. Achalkumar, D.S.S. Rao, S.K. Prasad, J. Org. Chem. 2007, 72, 8308-8318.

[39] K. Ohta, Y. Inagaki-Oka, H. Hasebe and I. Yamamoto, Polyhedron 2000, 19, 267-274.

[40] C.V. Yelamaggad, V.P. Tamilenthi, Tetrahedron 2009, 65, 6403-6409.

[41] a) K.D. Hodges, J.V. Rund, Inorg. Chem. 1975, 14, 525-528; b) A. Vacher, F. Barrière, F. Camerel, J.-F. Bergamini, T. Roisnel, D. Lorcy, Dalton Trans. 2013, 42, 383-394.

[42] S.-K. Lee, K.-S. Shin, D.-Y. Noh, O. Jeannin, F. Barriere, J.-F. Bergamini, M. Fourmigue, Chem. Asian J. 2010, 5, 169-176.

[43] J.H. Price, J.P. Birk, B.B. Wayland, Inorg. Chem. 1978, 17, 2245-2250. 